\title{
Location of the Phosphate Binding Site within Clostridium symbiosum Pyruvate Phosphate Dikinase ${ }^{\dagger, \ddagger}$
}

\author{
Marielena McGuire, ${ }^{\S}$ Kui Huang," Geeta Kapadia," Osnat Herzberg,*,ll and Debra Dunaway-Mariano*,L \\ Department of Chemistry and Biochemistry, University of Maryland, College Park, Maryland 27042, \\ Center for Advanced Research in Biotechnology, 9600 Gudelsky Drive, Rockville, Maryland 20850, \\ and Department of Chemistry, University of New Mexico, Albuquerque, New Mexico 87131
}

Received April 23, 1998; Revised Manuscript Received July 27, 1998

\begin{abstract}
Pyruvate phosphate dikinase (PPDK) catalyzes the interconversion of ATP, $\mathrm{P}_{\mathrm{i}}$, and pyruvate with AMP, $P_{\mathrm{i}}$, and PEP in three partial reactions: (1) E + ATP $\rightarrow$ E・ATP $\rightarrow$ E-PP·AMP, (2) E-PP• $\mathrm{AMP}+\mathrm{P}_{\mathrm{i}} \rightarrow \mathrm{E}-\mathrm{PP} \cdot \mathrm{AMP} \cdot \mathrm{P}_{\mathrm{i}} \rightarrow \mathrm{E}-\mathrm{P} \cdot \mathrm{AMP} \cdot \mathrm{PP}_{\mathrm{i}}$, and $(3) \mathrm{E}-\mathrm{P}+$ pyruvate $\rightarrow \mathrm{E}-\mathrm{P} \cdot$ pyruvate $\rightarrow \mathrm{E} \cdot \mathrm{PEP}$. The Clostridium symbiosum PPDK structure consists of $\mathrm{N}$-terminal, central, and $\mathrm{C}$-terminal domains. The $\mathrm{N}$-terminal and central domains catalyze partial reactions 1 and 2 whereas the $\mathrm{C}$-terminal and central domains catalyze partial reaction 3 . The goal of the present work is to determine where on the $\mathrm{N}$-terminal domain catalysis of partial reactions 1 and 2 occurs and, in particular, where the $\mathrm{P}_{\mathrm{i}}$ binding site is located. Computer modeling studies implicated Arg337 as a key residue for $\mathrm{P}_{\mathrm{i}}$ binding. This role was tested by site-directed mutagenesis. The R337A PPDK was shown to be impaired in catalysis of the forward $\left(k_{\mathrm{cat}}\right.$ 300 -fold lower) and reverse ( $k_{\mathrm{cat}} 30$-fold lower) full reactions. Time courses for the single turnover reactions were measured to show that catalysis of partial reaction 1 is 5 -fold slower in the mutant, catalysis of the second partial reaction is 140 -fold slower in the mutant, and catalysis of the third partial reaction is unaffected. With the exception of the mutation site, the crystal structure of the R337A PPDK closely resembles the structure of the wild-type protein. Thus, the altered kinetic properties observed for this mutant are attributed solely to the elimination of the interaction between substrate and the guanidinium group of the Arg337 side chain. On the basis of these findings we propose that the $\mathrm{P}_{\mathrm{i}}$ binding site is located within the crevice of the PPDK N-terminal domain, at a site that is flanked by the ATP $\beta$-P and the $\mathrm{Mg}^{2+}$ cofactor.
\end{abstract}

Pyruvate phosphate dikinase (PPDK) ${ }^{1}$ catalyzes the interconversion of ATP, $\mathrm{P}_{\mathrm{i}}$, and pyruvate with AMP, $\mathrm{PP}_{\mathrm{i}}$, and PEP in the presence of $\mathrm{Mg}^{2+}$ and $\mathrm{NH}_{4}^{+}$ion activators. PPDK is found in certain microbes and in certain plants where it functions in ATP production, replacing pyruvate kinase, or in PEP formation, replacing pyruvate carboxylase and PEP carboxykinase (1). The absence of PPDK in animals, coupled with its essential functioning in parasitic protists (e.g., Entamoeba histolytica, Giardia lamblia, and Trichomonas vaginalis), renders it a prime target for the design of antiparasitic agents (2). The genes encoding PPDK in Clostridium symbiosum, G. lamblia, E. histolytica, and several plants have been cloned and sequenced $(3,4)$. The

\footnotetext{
$\uparrow$ This work was supported by NIH Grant GM 36260 (D.D.-M.) and NSF Grant MCB9316934 (O.H.)

Coordinates have been deposited into the Brookhaven Protein Data Bank (entry code 2DIK).

* To whom correspondence should be addressed.

$\S$ University of Maryland.

"Center for Advanced Research in Biotechnology.

${ }^{\perp}$ University of New Mexico.

${ }^{1}$ Abbreviations: PPDK, pyruvate phosphate dikinase; ATP, adenosine 5'-triphosphate; ADP, adenosine 5'-diphosphate; AMP, adenosine 5'-monophosphate; PEP, phosphoenolpyruvate; NADH, dihydronicotinamide adenine dinucleotide; Hepes, $N$-(2-hydroxyethyl)piperazine$N^{\prime}$-2-ethanesulfonic acid; HPLC, high-performance liquid chromatography.
}

gene products are of similar size (884-953 amino acids), and the levels of amino acid identities existing between the paired PPDK sequences are high, ranging from 50\% to $60 \%$ for comparisons made between bacterial, protozoan and plant enzymes. The high level of sequence identity which exists between the dikinases is suggestive of a conserved structure.

The three-dimensional structure of the $C$. symbiosum apoPPDK was recently determined (5). The structure is organized into three consecutive domains (Figure 1). Despite the lack of significant sequence homology, the fold of the $\mathrm{N}$-terminal domain is similar to that of the nucleotide binding domains of the ATP/ADP converting enzymes D-Ala-D-Ala ligase (6), sucinnyl-CoA synthetase (7), and glutathione synthase (8), indicating that the N-terminal domain of PPDK may bind ATP. Affinity labeling studies carried out with radiolabeled azidoATP and 2', 3'-dialdehyde AMP have provided independent evidence that the nucleotide binding site is indeed located on the N-terminal domain (9). The central domain contains the catalytic histidine (His455) as demonstrated by radiolabeling experiments carried out with [32 P]PEP $(9,10)$. The C-terminal domain is an $\alpha, \beta$-barrel similar in fold to the pyruvate binding domain of pyruvate kinase (11). Site-directed mutagenesis and $\left[{ }^{14} \mathrm{C}\right]$ bromopyruvate affinity labeling of the enzyme have confirmed the 

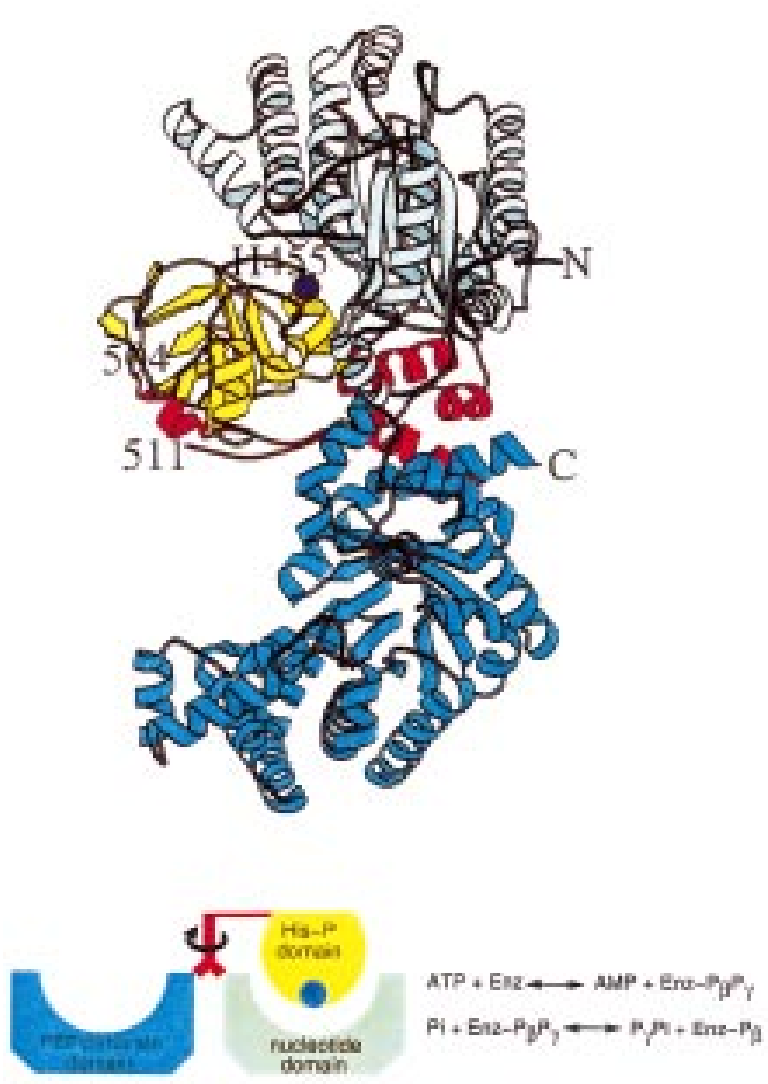
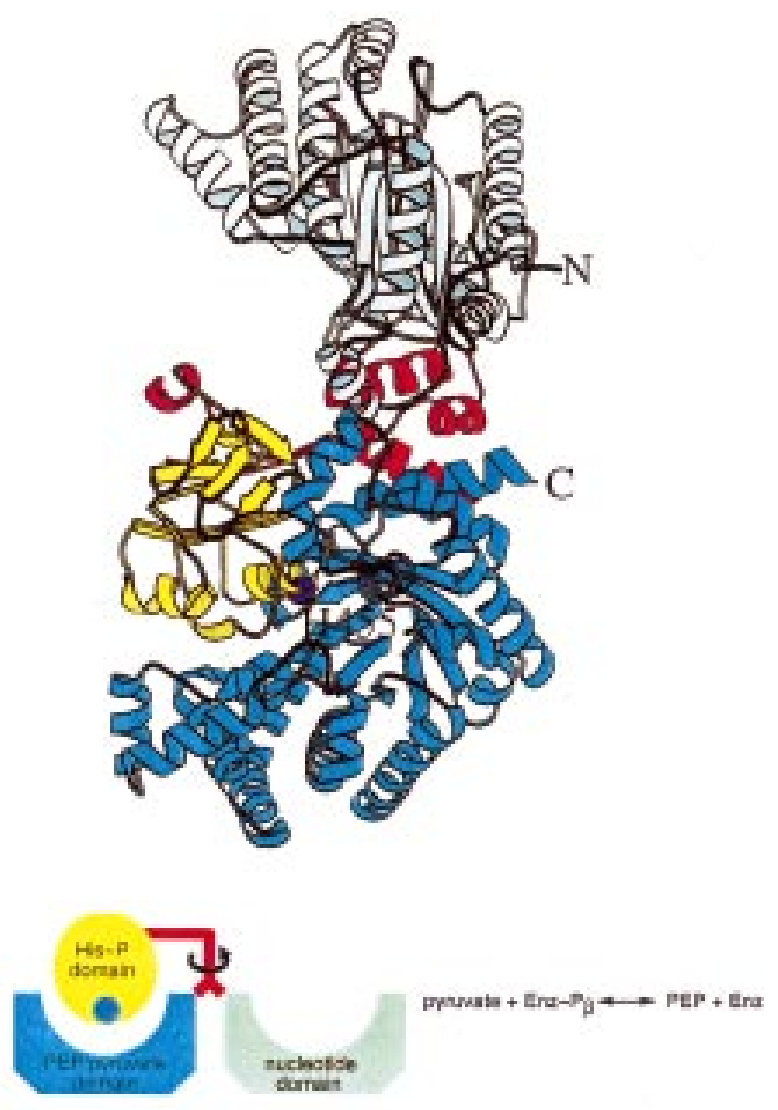

FIGURE 1: Ribbon diagram and simplified model of the C. symbiosum PPDK monomer adapted from ref 5 and illustrating the two conformational states of the protein yellow central histidine domain bound to the green $\mathrm{N}$-terminal nucleotide domain and the yellow central histidine domain bound to the blue $\mathrm{C}$-terminal pyruvate domain). The catalytic His 455 residue is represented by a purple sphere, and the discontinuity in the polypeptide chain observed in the crystal between residues 504 and 511 is marked. The first conformational state (the N-terminal domain bound to the central domain) is observed for the apoPPDK crystal structure, and the second conformation (the C-terminal domain bound to the central domain) has been obtained by a swivel motion of ca. $100^{\circ}$ around residue 380 .

Scheme 1: Partial Reactions of PPDK (15)

$E+A T P \rightarrow E \cdot A T P \rightarrow E-P P \cdot A M P$

$E \cdot P P \cdot A M P+P i \rightarrow E \cdot P P \cdot A M P \cdot P i \rightarrow E-P \cdot A M P \cdot P P_{i}$

E-P + pyruvate $\rightarrow$ E-P.pyruvate $\rightarrow$ E-P.PEP

Partial Reaction 3

pyruvate/PEP binding site location on the $\mathrm{C}$-terminal domain (Figure 1) (12). The determination of the location of the $\mathrm{P}_{\mathrm{i}}$ binding site on PPDK is the goal of the present study.

When bound to the N-terminal domain active site, the catalytic histidine abstracts the $\gamma, \beta$-PP unit from ATP (to form a pyrophosphorylated enzyme, $\mathrm{E}-\mathrm{PP}$ ) and then delivers the $\gamma-\mathrm{P}$ to $\mathrm{P}_{\mathrm{i}}$ (to form a phosphorylated enzyme, E-P) (13) (see Scheme 1). When bound to the C-terminal domain active site, located $45 \AA$ away from the ATP site, the phosphohistidine residue phosphorylates pyruvate. Studies carried out with PPDK truncation mutants have shown that only the $\mathrm{N}$-terminal domain and central domain are required to carry out the reaction steps: $\mathrm{E}+\mathrm{ATP}+\mathrm{P}_{\mathrm{i}} \rightarrow \mathrm{E}-\mathrm{PP}$. $\mathrm{P}_{\mathrm{i}} \cdot \mathrm{AMP} \rightarrow \mathrm{E}-\mathrm{P} \cdot \mathrm{PP}_{\mathrm{i}} \cdot \mathrm{AMP}(14)$. This observation suggests that the $\mathrm{P}_{\mathrm{i}}$ binding site is located on one of these two domains or, possibly, at their interface.

The original C. symbiosum PPDK structure determination was carried out on the apoenzyme crystallized from an ammonium sulfate solution (5). Since then, conditions to induce crystallization of the enzyme with metal cofactors and substrate/product ligands bound have been screened but have not yet produced crystals suitable for X-ray analysis. An alternative approach has employed the analogy to the structure of the D-Ala-D-Ala ligase- $\mathrm{Mg}^{2+}-\mathrm{ADP}-$ phosphinophosphate complex (6) to deduce a feasible model for $\mathrm{Mg}^{2+}$, ATP, and $\mathrm{P}_{\mathrm{i}}$ binding sites within the apoPPDK crystal structure $(5,9)$. On the basis of the orientation of ADP in the ligase structure, the adenine ring of the ATP was placed at the bottom of the cleft formed between the two $\beta$-sheets of the PPDK N-terminal domain (Figure 2). This location is consistent with the site of covalent labeling by photoaffinity agent azidoATP at the third $\beta$-strand from the front (residues 320-327), right $\beta$-sheet shown in Figure 2 . The ATP tripolyphosphate moiety was modeled toward the entrance of the cleft with the $\beta$-phosphoryl group aligned with the attacking catalytic His455 (with its side chain modified compared to the original apo structure). Two arrangements of the ATP $\gamma$-phosphoryl group were found to be compatible with the structure. In model $\mathrm{A}$, the $\gamma$-phosphoryl group interacts with a putative oxyanion hole formed by the backbone amide NH of Met103 and Gly101. It is also within an interaction distance of the Arg337 guanidinium group and the Lys 22 ammonium group. There is room for the $\mathrm{P}_{\mathrm{i}}$ ligand on the opposite side of the $\beta$-P where it will be within interaction distance of the $\operatorname{Arg} 337$ guanidinium group and the proposed site of the $\mathrm{Mg}^{2+}$ 

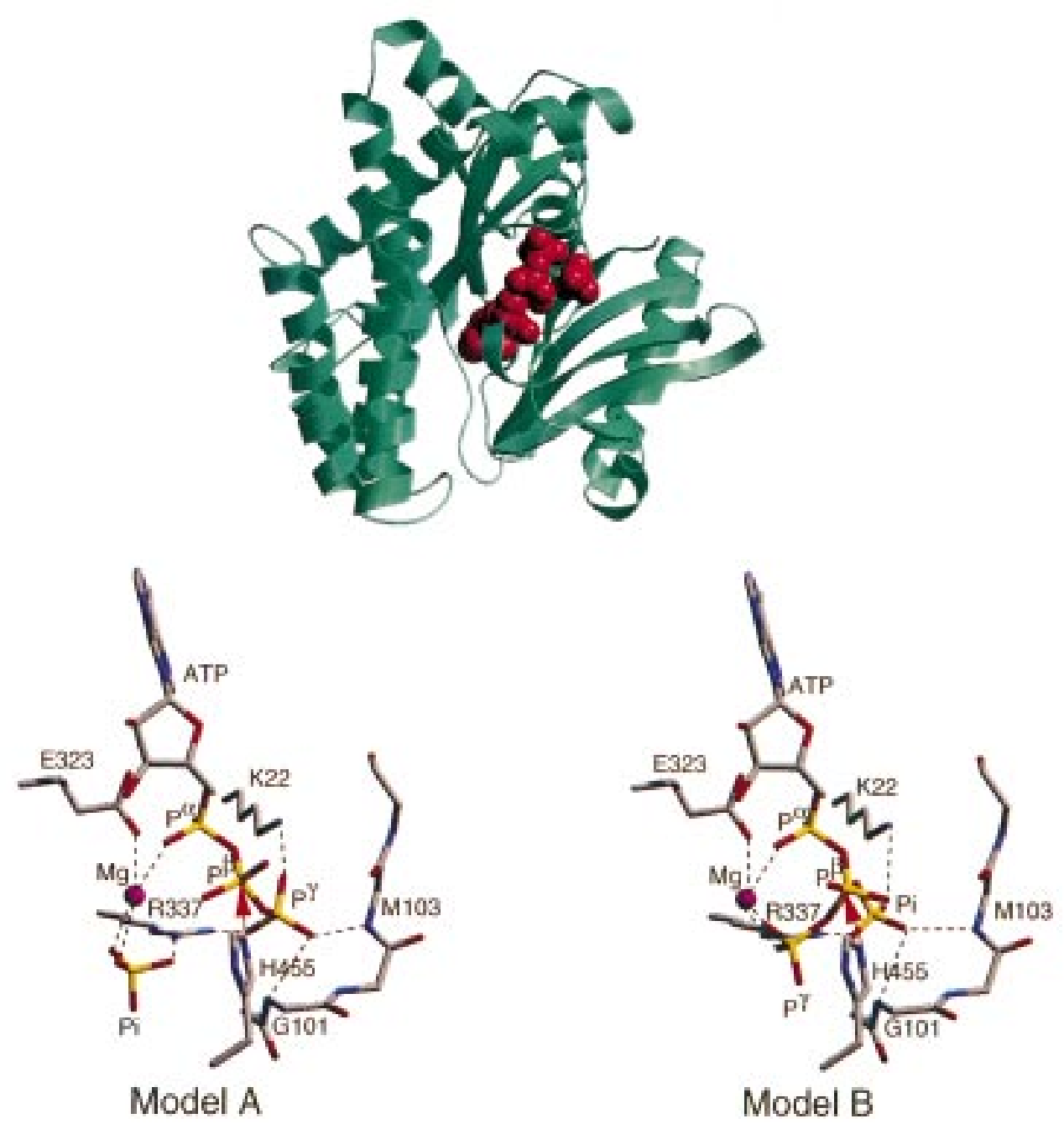

FIGURE 2: Ribbon diagram of the N-terminal domain (green) of $C$. symbiosum PPDK with modeled ATP and $\mathrm{P}_{\mathrm{i}}$ ligands (5) using the orientation illustrated in model A. The atomic models of the two possible binding modes of ATP and $\mathrm{P}_{\mathrm{i}}$ in the nucleotide binding site of PPDK are shown below. Atomic colors are used as follows: carbon, gray; oxygen, red; nitrogen, blue; phosphorus, yellow; $\mathrm{Mg}^{2+}$, magenta. Electrostatic interactions are shown as black dashed lines. The red arrow indicates the direction of attack of His 455 on the $\beta$-phosphate of ATP. Note that the side chain of His455 in the crystal structure (5) is not accessible to the active site, and its conformation was adjusted for in-line attack on the $\beta$-phosphate.

cofactor bound to Glu323. In model B, the $\gamma$-phosphoryl group and $\mathrm{P}_{\mathrm{i}}$ switch places. The $\gamma$-phosphoryl group now binds to the $\mathrm{Mg}^{2+}$ and to $\operatorname{Arg} 337$ whereas the $\mathrm{P}_{\mathrm{i}}$ is bound to the backbone amide NHs of the oxyanion hole and to the side chains of Lys22 and Arg337.

To test whether $\mathrm{P}_{\mathrm{i}}$ binds to the ATP binding cleft as suggested by the computer docking experiments, Arg337 was mutated. Our prediction was that if the ligands are oriented as shown in model A, the amino acid replacement may have only a small inhibitory effect on ATP binding and on catalysis of the E + ATP $\rightarrow$ E-PP·AMP partial reaction but a stronger inhibitory effect on $\mathrm{P}_{\mathrm{i}}$ binding and on catalysis of the $\mathrm{E}-\mathrm{PP} \cdot \mathrm{P}_{\mathrm{i}} \cdot \mathrm{AMP} \rightarrow \mathrm{E}-\mathrm{P} \cdot \mathrm{PP}_{\mathrm{i}} \cdot \mathrm{AMP}$ partial reaction. If, on the other hand, model $\mathrm{B}$ is correct, then mutation of Arg337 should strongly inhibit ATP binding and catalysis of the $\mathrm{E}+\mathrm{ATP} \rightarrow \mathrm{E}-\mathrm{PP} \cdot \mathrm{AMP}$ partial reaction while having a lesser effect on $\mathrm{P}_{\mathrm{i}}$ binding and catalysis of the $\mathrm{E}-\mathrm{PP} \cdot \mathrm{P}_{\mathrm{i}} \cdot$ $\mathrm{AMP} \rightarrow \mathrm{E}-\mathrm{P} \cdot \mathrm{PP}_{\mathrm{i}} \cdot \mathrm{AMP}$ partial reaction. If both models $\mathrm{A}$ and $\mathrm{B}$ are incorrect and $\mathrm{ATP}$ and $\mathrm{P}_{\mathrm{i}}$ are bound at sites remote from $\operatorname{Arg} 337$, then the kinetic properties of the $\operatorname{Arg} 337$ mutant are likely to be similar to those of wild-type PPDK.

In this paper we report on the preparation and steady-state kinetic properties of the R337A and R337K PPDK sitedirected mutants as well as on the X-ray crystal structure and pre-steady-state kinetic properties of the R337A PPDK mutant. Our findings indicate that, consistent with model A, Arg337 plays an important role in $\mathrm{P}_{\mathrm{i}}$ binding and catalysis of the $\mathrm{E}-\mathrm{PP} \cdot \mathrm{P}_{\mathrm{i}} \cdot \mathrm{AMP} \rightarrow \mathrm{E}-\mathrm{P} \cdot \mathrm{PP}_{\mathrm{i}} \cdot \mathrm{AMP}$ partial reaction and a comparatively small role in ATP binding and catalysis of the $\mathrm{E}+\mathrm{ATP} \rightarrow \mathrm{E}-\mathrm{PP} \cdot \mathrm{AMP}$ partial reaction.

\section{MATERIALS AND METHODS}

Materials. Plasmid pACYC184-D12 containing the cloned C. symbiosum PPDK gene is described by Pocalyko et al. (4). Escherichia coli JM101 cells (gift from John Gerlt) were grown to mid-log phase in LB media (containing $12.5 \mu \mathrm{g} /$ $\mathrm{mL}$ tetracycline) at $37^{\circ} \mathrm{C}$ before being harvested. Plasmid 
DNA used for sequencing and mutagenesis was obtained by using the method of Sambrook et al. (16). Primers used for PCR and sequencing reactions were purchased from Oligos Etc. Inc. Reagents used in PCR reactions were from the GeneAmp kit supplied by Perkin-Elmer Cetus. Reagents used in nucleotide sequencing were from the Sequenace kit purchased from USB. Enzymes used for DNA manipulation were purchased from New England Biolabs and from Promega. Coupling enzymes and enzymes used in the preparations of radiolabeled substrates were obtained from Sigma. The radiolabeled substrates $\left[\gamma-\right.$ or $\left.\beta-{ }^{32} \mathrm{P}\right] \mathrm{ATP},\left[{ }^{14} \mathrm{C}\right]-$ ATP, and $\left[{ }^{14} \mathrm{C}\right] \mathrm{AMP}$ were obtained from NEN. $\left[{ }^{14} \mathrm{C}\right]-$ Pyruvate was purchased from Amersham. [ $\left.{ }^{32} \mathrm{P}\right] \mathrm{PEP}$ was synthesized from $\left[\beta-{ }^{32} \mathrm{P}\right] \mathrm{ATP}$ according to the method reported by Carroll et al. (13).

Site-Directed Mutagenesis. R337A and R337K PPDK mutants were generated by using PCR techniques (17) in conjunction with a Thermolyne Temp Tronic thermocycler. The primary PCR reactions contained $50 \mathrm{mM} \mathrm{KCl}, 10 \mathrm{mM}$ Tris $\cdot \mathrm{HCl}(\mathrm{pH} 8.3), 200 \mu \mathrm{M}$ each of dATP, dCTP, dGTP, and dTTP, $20 \mathrm{pM}$ primer, 2.5 units of Taq DNA polymerase, $1.5 \mathrm{mM} \mathrm{MgCl}_{2}$, and $0.5 \mu \mathrm{g}$ of template DNA (pACYC184D12). The inside primers corresponded to sequence 10721089 while the outside primers corresponded to positions 926-942 and 2344-2360 (CGT to GCA change for R337A and CGT to AAA change for R337K). Reactions were overlaid with $50 \mu \mathrm{L}$ of sterile silica oil. Primary PCR reactions were carried out with denaturation at $92{ }^{\circ} \mathrm{C}$ for 1 min, annealing at $55^{\circ} \mathrm{C}$ for $1 \mathrm{~min}$, and extension at $72{ }^{\circ} \mathrm{C}$ for 2 min ( 25 cycles). Secondary PCR reactions were carried out using the following program: $2 \mathrm{~min}$ at $92{ }^{\circ} \mathrm{C} ; 5$ cycles of $1 \mathrm{~min}$ at $92{ }^{\circ} \mathrm{C}, 1 \mathrm{~min}$ at $47^{\circ} \mathrm{C}, 2 \mathrm{~min}$ at $72{ }^{\circ} \mathrm{C}$, and 3 min at $25{ }^{\circ} \mathrm{C}$; and 25 cycles of $1 \mathrm{~min}$ at $92{ }^{\circ} \mathrm{C}, 1 \mathrm{~min}$ at 50 ${ }^{\circ} \mathrm{C}$, and $2 \mathrm{~min}$ at $72{ }^{\circ} \mathrm{C}$. Following each PCR reaction, samples were chromatographed on 1\% LMP agarose electrophoresis gels using TBE buffer $(10.8 \mathrm{~g} / \mathrm{L}$ Tris, $5.5 \mathrm{~g} / \mathrm{L}$ boric acid, $0.84 \mathrm{~g} / \mathrm{L}$ EDTA). The DNA fragment was extracted from the gel using the Geneclean II kit from Bio 101 and cut along with the pACYC184-D12 plasmid with the restriction enzymes BstXI and KpnI. Following purification on the 1\% LMP agarose gel, the insert and linearized plasmid were ligated using T4 DNA ligase, and the resulting mixture was used to transform competent $E$. coli JM101 cells. Mutant colonies were initially screened by restriction enzyme digestion of plasmid DNA minipreps and then by nucleotide sequencing using the chain termination method (18).

Purification of Wild-Type and Mutant PPDK. The mutant and wild-type enzymes were purified as described in Wang et al. (19) and then subjected to an additional Sephacryl S-200 column chromatographic step $\left[4{ }^{\circ} \mathrm{C}, 20 \mathrm{mM}\right.$ imidazole Hydrochloride, $0.1 \mathrm{mM}$ EDTA, $1 \mathrm{mM}$ DTT, and $100 \mathrm{mM}$ $\mathrm{KCl}$ (pH 6.5) as eluant]. The enzyme was assayed during purification using the published spectrophotometric assay (19) and analyzed for purity at each stage by SDS-PAGE.

Steady-State Kinetic Analysis. (A). ATP-Forming Direction. The spectrophotometric assay (19) was used to monitor the initial velocity of the PPDK-catalyzed reaction of AMP, $\mathrm{PP}_{\mathrm{i}}$, and PEP to ATP, $\mathrm{P}_{\mathrm{i}}$, and pyruvate. Initial velocities were measured as a function of the concentration of the varied substrate (in a range of $0.5-10$-fold $K_{\mathrm{m}}$ ) at fixed, saturating concentrations of cosubstrates (0.5 mM AMP, 0.5 $\mathrm{mM}$ PEP, and $1 \mathrm{mM} \mathrm{PP}_{\mathrm{i}}$ for wild-type PPDK and $2.5 \mathrm{mM}$
$\mathrm{PP}_{\mathrm{i}}$ for mutant PPDK) and metal ion cofactors (5 $\mathrm{mM} \mathrm{MgCl}$ and $40 \mathrm{mM} \mathrm{NH}_{4} \mathrm{Cl}$ ) in $20 \mathrm{mM}$ imidazole ( $\mathrm{pH} 6.8,25^{\circ} \mathrm{C}$ ). The initial velocity data were analyzed using eq 1 . The $k_{\text {cat }}$ was calculated from $V_{\max } /[\mathrm{E}]$.

$$
v_{0}=V_{\max }[\mathrm{E}][\mathrm{S}] /\left(K_{\mathrm{m}}+[\mathrm{S}]\right)
$$

where $v_{0}$ is the initial velocity, [E] is the enzyme concentration, [S] is the substrate concentration, $V_{\max }$ is the maximum velocity, and $K_{\mathrm{m}}$ is the Michaelis constant.

(B). AMP-Forming Direction. Reaction solutions $(80 \mu \mathrm{L})$ containing $1 \mu \mathrm{M}$ wild-type PPDK or $20 \mu \mathrm{M}$ mutant PPDK, $2 \mathrm{mM}\left[{ }^{14} \mathrm{C}\right] \mathrm{ATP}, 5 \mathrm{mM}$ pyruvate, $5 \mathrm{mM} \mathrm{P}$, $5 \mathrm{mM} \mathrm{MgCl}_{2}$, $10 \mathrm{mM} \mathrm{NH}_{4} \mathrm{Cl}$, and 20 units of inorganic pyrophosphatase (to drive the reaction to completion by catalyzing $\mathrm{PP}_{\mathrm{i}}$ hydrolysis) in $50 \mathrm{mM} \mathrm{K} \mathrm{K}^{+}$Hepes $\left(\mathrm{pH} \mathrm{7.0,25}{ }^{\circ} \mathrm{C}\right.$ ) were quenched at specified times with $164 \mu \mathrm{L}$ of $0.6 \mathrm{M} \mathrm{HCl}$. The protein was precipitated by vortexing the quenched reaction with $100 \mu \mathrm{L}$ of $\mathrm{CCl}_{4}$ and then removed by centrifugation. ATP and AMP were separated from the supernatant by HPLC using a $4.6 \mathrm{~mm} \times 25 \mathrm{~cm}$ Beckman ultrasphere C18 reversed-phase analytical column and $25 \mathrm{mM} \mathrm{KH}_{2} \mathrm{PO}_{4}, 2.5 \%$ triethylamine, and $5 \%$ methanol as eluant $(1 \mathrm{~mL} / \mathrm{min}$ flow rate). The radioactivity of the ATP and AMP fractions was determined by scintillation counting.

Rapid Quench Experiments. Single turnover reactions were carried out by mixing $40 \mu \mathrm{L}$ of buffered enzyme-metal cofactor solution with $40 \mu \mathrm{L}$ of buffered substrate (limiting radiolabeled substrate and saturating unlabeled cosubstrate) solution in a KinTek rapid quench at $25^{\circ} \mathrm{C}$. The reactions were quenched at specified times with $164 \mu \mathrm{L}$ of $0.6 \mathrm{M} \mathrm{HCl}$. The protein was precipitated by vortexing the quenched reaction with $100 \mu \mathrm{L}$ of $\mathrm{CCl}_{4}$ and then collected by centrifugation. The protein pellet was analyzed for radioactivity by dissolving it in $500 \mu \mathrm{L}$ of boiling $10 \mathrm{~N} \mathrm{H}_{2} \mathrm{SO}_{4}$ and then subjecting the resulting solution to scintillation counting. The reaction sample supernatant fraction was separated into product and reactant using HPLC techniques. ATP and AMP were separated using a $4.6 \mathrm{~mm} \times 25 \mathrm{~cm}$ Beckman Ultrasphere $\mathrm{C} 18$ reversed-phase analytical column and $25 \mathrm{mM} \mathrm{KH}_{2} \mathrm{PO}_{4}, 2.5 \%$ triethylamine, and $5 \%$ methanol as eluant $(1 \mathrm{~mL} / \mathrm{min}$ flow rate). $\mathrm{PEP}$ and pyruvate were separated using a $4.6 \mathrm{~mm} \times 25 \mathrm{~cm}$ Beckman ultrasil anionexchange column and $0.4 \mathrm{M} \mathrm{KCl}$ and $0.1 \mathrm{M} \mathrm{KH}_{2} \mathrm{PO}_{4}(\mathrm{pH}$ $2.75)$ as eluant $(1.5 \mathrm{~mL} / \mathrm{min}$ flow rate). The amounts of ATP, $\mathrm{PP}_{\mathrm{i}}$, and $\mathrm{P}_{\mathrm{i}}$ in the reaction supernatants were determined by subjecting one $50 \mu \mathrm{L}$ aliquot to HPLC chromatography to separate the ATP for quantitation by liquid scintillation counting. A second aliquot $(50 \mu \mathrm{L})$ was added to $800 \mu \mathrm{L}$ of water and then mixed with $50 \mu \mathrm{L}$ of $6 \mathrm{M} \mathrm{HCl}$ and $75 \mu \mathrm{L}$ of $250 \mathrm{mM}$ ammonium molybdate. This solution was extracted with an equal volume of a 1:1 2-propanol-water mixture. The organic phase was assayed for $\left[{ }^{32} \mathrm{P}\right] \mathrm{P}_{\mathrm{i}}$ and the aqueous layer for $\left.{ }^{32 \mathrm{P}}\right] \mathrm{PP}_{\mathrm{i}}$ by liquid scintillation counting. The single turnover time courses were constructed by plotting the concentration of reactant, intermediate, and/or product present in the reaction as a function of reaction time. The data were analyzed using the computer program Kalidograph and a single exponential equation.

$X$-ray Crystallographic Analysis of R337A PPDK. The crystallization conditions used for the $C$. symbiosum R337A PPDK mutant were the same as those used for the wild- 


\begin{tabular}{ll} 
Table 1: Statistics of X-ray Crystallographic Data Collection for \\
R337A PPDK \\
\hline space group & $\begin{array}{l}P 2_{1} \\
\text { cell parameters }\end{array}$ \\
& $c=89.9 \AA, b=58.7 \AA$, \\
maximum resolution $(\AA)$ & 2.5 \\
no. of crystals used & 1 \\
no. of observations & 97563 \\
no. of unique reflections & 35455 \\
$R_{\text {merge }}{ }^{a}$ & 0.099 \\
completeness $(\%)$ & $95(83)^{b}$ \\
$I / \sigma(I)$ & $10.2(1.2)^{b}$ \\
\hline${ }^{a} R_{\text {merge }}=\sum_{h k l}\left[\left(\sum_{i}\left|I_{i}-\langle I\rangle\right|\right) / \sum_{i} I_{i}\right] .{ }^{b}$ The values in parentheses cor- \\
respond to the highest resolution shell between 2.66 and $2.50 \AA$.
\end{tabular}

type enzyme (5). Single crystals were obtained at $30^{\circ} \mathrm{C}$ by vapor diffusion in hanging drops. Protein drops were equilibrated against reservoir solutions containing 50-55\% saturated ammonium sulfate and $100 \mathrm{mM}$ Hepes buffer, $\mathrm{pH}$ 7.0. The drops consisted of protein at $\sim 10 \mathrm{mg} / \mathrm{mL}, 20 \mathrm{mM}$ imidazole buffer, $\mathrm{pH} 6.5,100 \mathrm{mM} \mathrm{KCl}, 0.1 \mathrm{mM}$ EDTA, and $1 \mathrm{mM}$ mercaptoethanol diluted by an equal volume of reservoir solution. The crystals belong to the space group $P 2$, and within the accuracy of the data the unit cell dimensions are the same as those of the wild-type protein crystals (Table 1). X-ray diffraction data were collected on a Siemens area detector mounted on a three-circle goniostat, with a monochromated $\mathrm{Cu} \mathrm{K} \alpha \mathrm{X}$-ray supplied by a Rigaku Rotaflex RU200BH rotating anode generator. Data were processed with the XENGEN package (20). Data collection statistics are provided in Table 1 . Initial structure refinement was performed with the program X-PLOR (21). The simulated annealing slow-cooling protocol at $3000 \mathrm{~K}$ was followed by positional refinement cycles. Data between 8.0 and $2.5 \AA$ for which $F \geq 3 \sigma(F)$ were included. Adjustments to the model were made on a Silicon Graphics INDIGO II computer graphics workstation using the program TURBOFRODO (22). The later stages of refinement were performed with the program TNT (23) including data between 10 and $2.5 \AA$ for which $F \geq 2 \sigma(F)$.

\section{RESULTS}

Purification and Characterization of R337A and R337K $P P D K$. The R337A and R337K PPDK mutants were generated using the pACYC184-D12 clone (4) in conjunction with standard PCR techniques (17). Both mutants behaved similarly to the wild-type PPDK during the purification steps, eluting from the DEAE-cellulose and Sephacryl-200 columns in the same positions as wild-type enzyme. The yield of purified wild-type PPDK is $15 \mathrm{mg} / \mathrm{g}$ of cell, the yield of R337A PPDK is $9 \mathrm{mg} / \mathrm{g}$ of cell, and the yield of R337K PPDK is $3 \mathrm{mg} / \mathrm{g}$ of cell. The resistance of the purified mutant enzymes toward proteolytic fragmentation during storage in $\mathrm{pH} 7$ buffer at $4{ }^{\circ} \mathrm{C}$ was examined over a 1 month period and found to be the same as that of wild-type enzyme. In previous studies of PPDK mutants we discovered that the tendency of the enzyme to undergo fragmentation during purification and/or prolonged storage is a reliable indicator of unstable or nonnative-like structure (12). On the basis of these criteria the R337A and R337K PPDK mutants appear to have a native fold, which in the case of the R337A PPDK was later confirmed by X-ray crystal structure determination (see below).

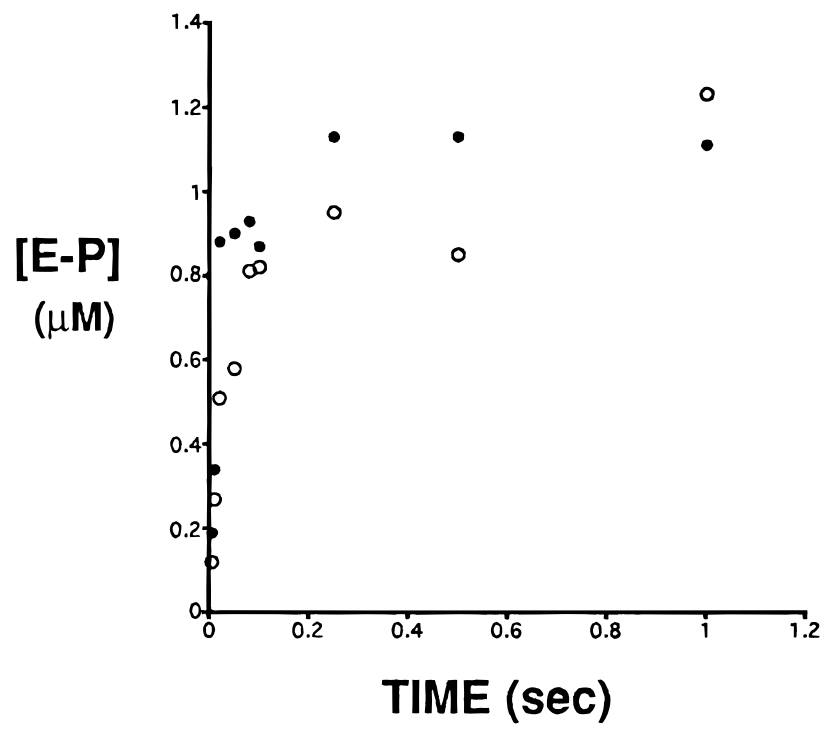

FIGURE 3: Time course for $\left[{ }^{32} \mathrm{P}\right] \mathrm{E}-\mathrm{P}$ formation in the single turnover reaction of $40 \mu \mathrm{M}$ enzyme, $5 \mu \mathrm{M}\left[{ }^{32} \mathrm{P}\right] \mathrm{PEP}, 2.5 \mathrm{mM}$ $\mathrm{MgCl}_{2}$, and $10 \mathrm{mM} \mathrm{NH}_{4} \mathrm{Cl}$ in $50 \mathrm{mM} \mathrm{K}^{+}$HEPES (pH 7.0, $25^{\circ} \mathrm{C}$ ) catalyzed by $40 \mu \mathrm{M}$ (๑) wild-type PPDK and (O) R337A PPDK.

Steady-State Kinetic Analysis of Wild-Type and Mutant PPDK Catalysis. The PPDK-catalyzed reaction is fully reversible, thus allowing kinetic measurements to be made for the forward and reverse reaction directions. The ATP $+\mathrm{P}_{\mathrm{i}}+$ pyruvate $\rightarrow \mathrm{AMP}+\mathrm{PP}_{\mathrm{i}}+\mathrm{PEP}$ reaction was monitored using a fixed time assay in which $\left[{ }^{14} \mathrm{C}\right] \mathrm{ATP}$ is used as the radiolabeled substrate and HPLC methods are employed to separate unconsumed ATP and AMP product from the quenched reaction solution. Inorganic pyrophosphatase was included to hydrolyze the $\mathrm{PP}_{\mathrm{i}}$ formed, thus driving the reaction to completion. Saturating substrate and cofactor concentrations were used $\left(2 \mathrm{mM}\left[{ }^{14} \mathrm{C}\right] \mathrm{ATP}, 5 \mathrm{mM}\right.$ $\mathrm{P}_{\mathrm{i}}, 5 \mathrm{mM}$ pyruvate, $5 \mathrm{mM} \mathrm{MgCl}_{2}$, and $10 \mathrm{mM} \mathrm{NH}_{4} \mathrm{Cl}$ in 20 $\mathrm{mM}$ imidazole hydrochloride, $\mathrm{pH}$ 6.8) so that the initial velocity of the reaction approximates the maximum velocity. A plot of $\left[{ }^{14} \mathrm{C}\right] \mathrm{AMP}$ concentration vs reaction time was constructed for each of the three reactions (see Figures 1-3, Supporting Information). The initial velocity was calculated from the slope of the computer fit of the initial time points to a linear equation. The ratio of the initial velocity $(\mathrm{mM} /$ $\min ; 0.32 \pm 0.02$ wild-type, $0.020 \pm 0.0005 \mathrm{R} 337 \mathrm{~K}$, and $0.0053 \pm 0.00004 \mathrm{R} 337 \mathrm{~A})$ and enzyme concentration $(1 \mu \mathrm{M}$ wild-type PPDK, $2 \mu \mathrm{M}$ R337K PPDK, or $20 \mu \mathrm{M}$ R337A PPDK) defines the $k_{\text {cat }}$ for the reaction providing that cofactors and substrates are present in the reaction solution at saturating concentrations. In the case of the wild-type enzyme the saturating conditions are met (19) and, thus, $k_{\text {cat }}$ $=5.4 \mathrm{~s}^{-1}$. The $K_{\mathrm{m}}$ values for the three substrates with the two mutants are not known and, therefore, the $k_{\text {cat }}=0.17$ $\mathrm{s}^{-1}\left(\mathrm{R} 337 \mathrm{~K}\right.$ PPDK) and $k_{\mathrm{cat}}=0.016 \mathrm{~s}^{-1}$ (R337A PPDK) values determined here may be less than or equal to the true $k_{\text {cat }}$ values. Nevertheless, the 30 -fold decrease in the observed $k_{\text {cat }}$ determined for R337K PPDK and the 300-fold decrease in the observed $k_{\text {cat }}$ determined for R337A PPDK indicate that Arg 337 plays an important but not an essential role in catalysis.

The AMP $+\mathrm{PP}_{\mathrm{i}}+\mathrm{PEP} \rightarrow \mathrm{ATP}+\mathrm{P}_{\mathrm{i}}+$ pyruvate reaction was monitored using a continuous spectrophotometric assay in which pyruvate formation is coupled with lactate dehydrogenase catalyzed NADH oxidation (19). The initial 
Table 2: Steady-State Kinetic Constants for Wild-Type PPDK, R337A PPDK, and R337K PPDK Catalysis

\begin{tabular}{|c|c|c|c|}
\hline \multicolumn{4}{|c|}{ (I) Reaction: ATP $+\mathrm{P}_{\mathrm{i}}+$ pyruvate $\rightarrow \mathrm{AMP}+\mathrm{PP}_{\mathrm{i}}+\mathrm{PEP}^{a}$} \\
\hline enzyme & \multicolumn{2}{|c|}{$V_{\max }(\mathrm{mM} / \min )$} & $k_{\text {cat }}\left(\mathrm{s}^{-1}\right)$ \\
\hline wild type $(1 \mu \mathrm{M})$ & \multicolumn{2}{|c|}{$0.32 \pm 0.02$} & 5.4 \\
\hline $\mathrm{R} 337 \mathrm{~A}(20 \mu \mathrm{M})$ & \multicolumn{2}{|c|}{$0.019 \pm 0.0008^{a}$} & 0.016 \\
\hline $\mathrm{R} 337 \mathrm{~K}(2 \mu \mathrm{M})$ & \multicolumn{2}{|c|}{$0.020 \pm 0.0005^{a}$} & 17 \\
\hline \multicolumn{4}{|c|}{ (II) Reaction: $\mathrm{AMP}+\mathrm{PP}_{\mathrm{i}}+\mathrm{PEP} \rightarrow \mathrm{ATP}+\mathrm{P}_{\mathrm{i}}+$ pyruvate $^{b}$} \\
\hline sample & $K_{\mathrm{m}}(\mathrm{mM})$ & $V_{\max }(\mathrm{mM} / \mathrm{min})$ & $k_{\text {cat }}\left(\mathrm{s}^{-1}\right)$ \\
\hline \multicolumn{4}{|l|}{ wild type $(0.016 \mu \mathrm{M})$} \\
\hline vary $\mathrm{AMP}^{c}$ & $0.007 \pm 0.0005$ & $0.026 \pm 0.001$ & 26 \\
\hline vary $\mathrm{PP}_{\mathrm{i}}^{d}$ & $0.07 \pm 0.01$ & $=0.004$ & 30 \\
\hline varyPEP ${ }^{e}$ & $0.027 \pm 0.0005$ & $0.029 \pm 0.0004$ & 36 \\
\hline \multicolumn{4}{|l|}{ R337A $(0.22 \mu \mathrm{M})$} \\
\hline vary $\mathrm{AMP}^{f}$ & $0.006 \pm 0.0005$ & $0.014 \pm 0.0004$ & 1.1 \\
\hline vary $\mathrm{PP}_{\mathrm{i}}^{d}$ & $1.14 \pm 0.121$ & $0.019 \pm 0.001$ & 1.4 \\
\hline vary $\mathrm{PEP}^{g}$ & $0.009 \pm 0.0006$ & $0.010 \pm 0.0002$ & 0.8 \\
\hline \multicolumn{4}{|l|}{ R337K $(0.032 \mu \mathrm{M})$} \\
\hline vary $\mathrm{AMP}^{f}$ & $0.006 \pm 0.003$ & $0.016 \pm 0.0004$ & 8.2 \\
\hline vary $\mathrm{PP}_{\mathrm{i}}^{d}$ & $0.477 \pm 0.04$ & 0.0007 & 10.4 \\
\hline vary $\mathrm{PEP}^{g}$ & $0.021 \pm 0.002$ & $0.016 \pm 0.0006$ & 8.3 \\
\hline
\end{tabular}

a $2 \mathrm{mM}\left[{ }^{14} \mathrm{C}\right] \mathrm{ATP}, 5 \mathrm{mM}$ pyruvate, $5 \mathrm{mM} \mathrm{P}$, 20 units of inorganic pyrophosphatase, $5 \mathrm{mM} \mathrm{MgCl}_{2}, 10 \mathrm{mM} \mathrm{NH}_{4} \mathrm{Cl}$, and $50 \mathrm{mM} \mathrm{K}^{+}$Hepes (pH 7.0, $\left.25^{\circ} \mathrm{C}\right) .{ }^{b} 20 \mathrm{mM}$ imidazole hydrochloride (pH 6.8), $40 \mathrm{mM}$ $\mathrm{NH}_{4} \mathrm{Cl}$, and $5 \mathrm{mM} \mathrm{MgCl} 2$ at $25^{\circ} \mathrm{C}$. ${ }^{c}$ Reactions contained $1.0 \mathrm{mM} \mathrm{PP}$ and $0.5 \mathrm{mM}$ PEP. ${ }^{d}$ Reactions contained $0.5 \mathrm{mM}$ AMP and $0.5 \mathrm{mM}$ PEP. ${ }^{e}$ Reactions contained $1.0 \mathrm{mM} \mathrm{PP}$ and $0.5 \mathrm{mM}$ AMP. ${ }^{f}$ Reactions contained $2.5 \mathrm{mM} \mathrm{PP}_{\mathrm{i}}$ and $0.5 \mathrm{mM}$ PEP. ${ }^{g}$ Reactions contained $2.5 \mathrm{mM}$ $\mathrm{PP}_{\mathrm{i}}$ and $0.5 \mathrm{mM}$ AMP.

velocities, measured for reactions in which one substrate concentration was varied while the concentrations of the two cosubstrates were saturating and fixed, were used to calculate $V_{\max }$ and $K_{\mathrm{m}}$. The results, summarized in Table 2, show that $k_{\text {cat }}$ is reduced 3-fold for R337K PPDK and 30-fold for R337A PPDK. The $K_{\mathrm{m}}$ values measured for the mutants deviate significantly from those of wild-type only in the case of the $\mathrm{PP}_{\mathrm{i}}$ substrate. For $\mathrm{R} 337 \mathrm{~K}$ PPDK the $\mathrm{PP}_{\mathrm{i}} K_{\mathrm{m}}$ is increased 7-fold and for R337A PPDK, 20-fold. This result suggests that Arg337 may play an important role in the E-P $+\mathrm{AMP}+\mathrm{PP}_{\mathrm{i}} \rightarrow \mathrm{E}+\mathrm{ATP}+\mathrm{P}_{\mathrm{i}}$ partial reaction (see Scheme 1).

Transient Kinetic Analysis of Wild-Type and Mutant PPDK Catalysis. The rates of the three PPDK partial reactions represented in Scheme 1 were measured by carrying out single turnover reactions with PPDK and specifically radiolabeled substrate. A rapid quench device was used to mix a solution of radiolabeled substrate and cosubstrate/cofactors with a solution of enzyme and, then, to terminate the reaction after a specified period of time by the addition of acid. The composition of the quenched reaction mixture was determined by first separating radiolabeled enzyme by precipitation and then radiolabeled substrate and product by HPLC. The enzyme, reactant, and product fractions were quantitated by liquid scintillation counting. For the first set of experiments, $\left[{ }^{32} \mathrm{P}\right] \mathrm{PEP}$ was used as substrate to monitor phosphorylenzyme formation in the $\mathrm{E} \cdot \mathrm{PEP} \rightarrow \mathrm{E}-\mathrm{P} \cdot$ pyruvate partial reaction and $\left[{ }^{14} \mathrm{C}\right] \mathrm{AMP}$ was used as substrate to monitor ATP formation from the E-P.AMP.PP $\rightarrow E-P P \cdot A M P \cdot P_{i} \rightarrow E \cdot$ $A T P \cdot P P_{i}$ reaction sequence. For the second set of experiments, $\left[{ }^{14} \mathrm{C}\right] \mathrm{ATP}$ was used as substrate and $\left[{ }^{14} \mathrm{C}\right] \mathrm{AMP}$ formation from $\mathrm{E} \cdot \mathrm{ATP} \rightarrow \mathrm{E}-\mathrm{PP} \cdot \mathrm{AMP}$ and from $\mathrm{E} \cdot \mathrm{ATP} \cdot \mathrm{P}_{\mathrm{i}}$ $\rightarrow \mathrm{E}-\mathrm{PP} \cdot \mathrm{AMP} \cdot \mathrm{P}_{\mathrm{i}} \rightarrow \mathrm{E}-\mathrm{P} \cdot \mathrm{AMP} \cdot \mathrm{PP}_{\mathrm{i}}$ was monitored. For the last set of experiments $[\gamma$-ATP] was used as substrate
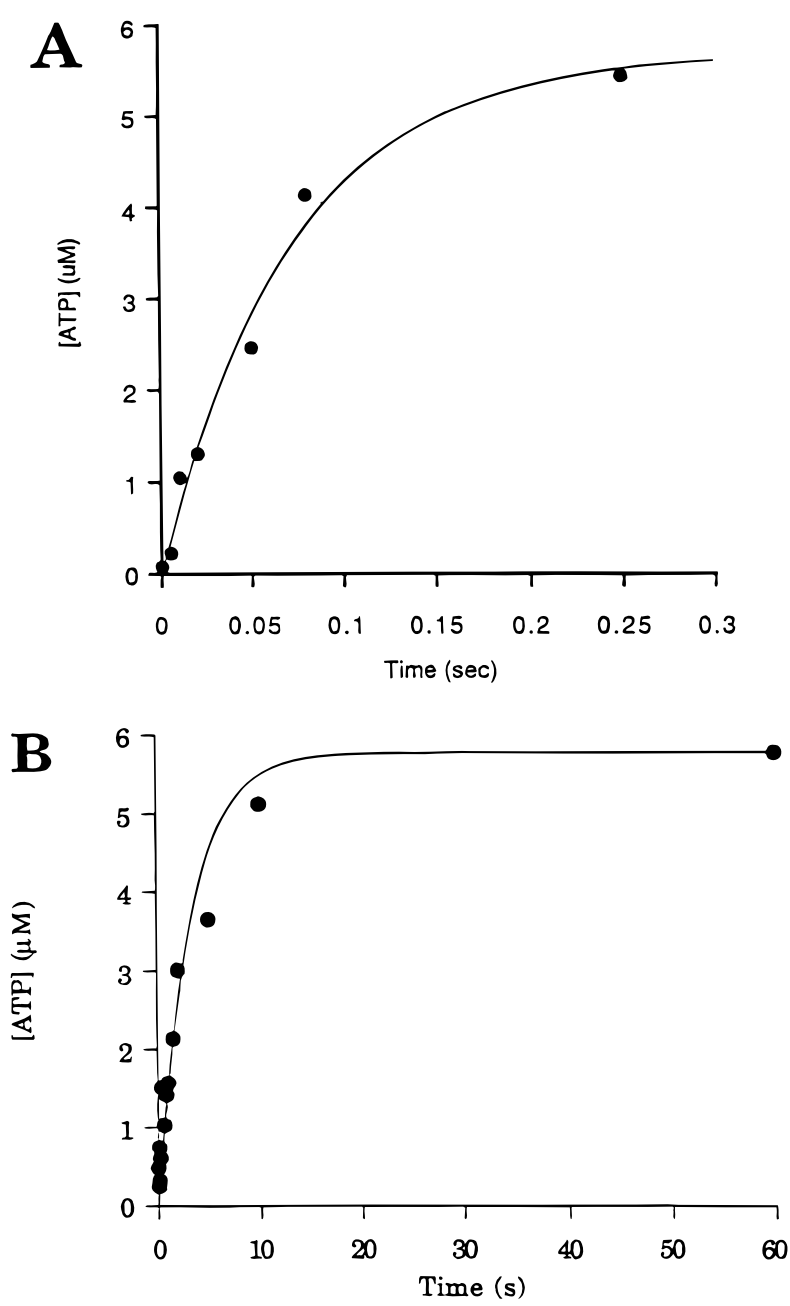

FIGURE 4: Time course for $\left[{ }^{14} \mathrm{C}\right] \mathrm{ATP}$ formation in the single turnover reaction of $40 \mu \mathrm{M}$ enzyme, $80 \mu \mathrm{M}$ PEP, $6 \mu \mathrm{M}\left[{ }^{14} \mathrm{C}\right] \mathrm{AMP}$, $2 \mathrm{mM} \mathrm{PP}_{\mathrm{i}}, 5 \mathrm{mM} \mathrm{MgCl}_{2}$, and $10 \mathrm{mM} \mathrm{NH}_{4} \mathrm{Cl}$ in $50 \mathrm{mM} \mathrm{K}^{+} \mathrm{HEPES}$ $\left(\mathrm{pH} 7.0,25^{\circ} \mathrm{C}\right.$ ). Panels: (A) wild-type PPDK and (B) R337A PPDK.

and the formation of ${ }^{32} \mathrm{P}$-labeled $\mathrm{E}-\mathrm{PP}$ and $\left[{ }^{32} \mathrm{P}\right] \mathrm{PP}_{\mathrm{i}}$ was measured.

The single turnover experiments were carried for the purpose of determining which of the three partial reactions (Scheme 1) is inhibited by the replacement of Arg337. If model A (Figure 2) is correct, R337A PPDK is predicted to be strongly inhibited in the catalysis of partial reaction 2 , moderately inhibited in the catalysis of partial reaction 1 , and not inhibited in the catalysis of partial reaction 3. If, on the other hand, model B is correct, catalysis of partial reaction 1 will be strongly inhibited, catalysis of partial reaction 2 moderately inhibited, and catalysis of partial reaction 3 unaffected.

The first step taken was to show that the rate of a single turnover of $\mathrm{E}+\mathrm{PEP} \rightarrow \mathrm{E}-\mathrm{P}+$ pyruvate (partial reaction 3 ) is unaffected by the Arg337 mutation. Figure 3 shows the time courses for the single turnover reactions of $40 \mu \mathrm{M}$ wild-type or R337A PPDK with $5 \mu \mathrm{M}\left[{ }^{32} \mathrm{P}\right] \mathrm{PEP}$. The data were fit to a single exponential equation to yield $k_{\mathrm{obs}}=45$ $\pm 8 \mathrm{~s}^{-1}$ for wild-type PPDK and $k_{\mathrm{obs}}=25 \pm 5 \mathrm{~s}^{-1}$ for R337A PPDK. It is clear from these data that R337A PPDK catalyzes the $\mathrm{E}+\mathrm{PEP} \rightarrow \mathrm{E}-\mathrm{P}+$ pyruvate partial reaction as efficiently as does wild-type PPDK. Figure 4, on the other hand, shows the time courses for the single turnover reactions 
of $40 \mu \mathrm{M}$ wild-type or R337A PPDK with $80 \mu \mathrm{M}$ PEP +6 $\mu \mathrm{M}\left[{ }^{14} \mathrm{C}\right] \mathrm{AMP}+4 \mathrm{mM} \mathrm{PP}$. The data were fit to a single exponential equation to yield $k_{\mathrm{obs}}=15 \pm 1 \mathrm{~s}^{-1}$ for wildtype PPDK and $k_{\mathrm{obs}}=0.59 \pm 0.02 \mathrm{~s}^{-1}$ for R337A PPDK. From these data we conclude that the Arg337 mutant catalyzes the $\mathrm{E}+\mathrm{AMP}+\mathrm{PP}_{\mathrm{i}}+\mathrm{PEP} \rightarrow \mathrm{E}+\mathrm{ATP}+\mathrm{P}_{\mathrm{i}}+$ pyruvate reaction 30 -fold less efficiently than wild-type PPDK. Together, the kinetic data in Figures 3 and 4 indicate that the replacement of Arg337 does not inhibit catalysis of $\mathrm{E}+\mathrm{PEP} \rightarrow \mathrm{E}-\mathrm{P}+$ pyruvate (partial reaction 3 ) but it does inhibit catalysis of E-P + AMP $+\mathrm{PP}_{\mathrm{i}} \rightarrow \mathrm{E}+\mathrm{ATP}+\mathrm{P}_{\mathrm{i}}$ (partial reactions 2 and 1 ).

The next step was to determine which partial reaction, $\mathrm{E}$ $+\mathrm{ATP} \rightarrow \mathrm{E}-\mathrm{PP} \cdot \mathrm{AMP}$ or E-PP·AMP $+\mathrm{P}_{\mathrm{i}} \rightarrow \mathrm{E}-\mathrm{P} \cdot \mathrm{AMP} \cdot$ $\mathrm{PP}_{\mathrm{i}}$, is inhibited by the $\mathrm{Arg} 337$ replacement. First, the rate of the E + ATP $\rightarrow$ E-PP·AMP reaction catalyzed by R337A PPDK was measured and compared to that catalyzed by wildtype PPDK. This was accomplished by reacting limiting $\left[{ }^{14} \mathrm{C}\right]$ ATP $(5 \mu \mathrm{M})$ with excess enzyme $(40 \mu \mathrm{M})$ in the presence of saturating $\mathrm{Co}^{2+}$ and $\mathrm{NH}_{4}{ }^{+}$cofactors and measuring the time course for $\left[{ }^{14} \mathrm{C}\right] \mathrm{AMP}$ formation in the enzyme active site during a single turnover. $\mathrm{Co}^{2+}$ was used in this reaction in place of the physiological $\mathrm{Mg}^{2+}$ cofactor for the purpose of enhancing the yield of the E-PP-AMP product formed at equilibrium. ${ }^{2}$ For wild-type PPDK, the rate constant for ATP binding is ca. $5 \mu \mathrm{M}^{-1} \mathrm{~s}^{-1}$ while the rate constant for $\mathrm{E} \cdot \mathrm{ATP} \rightarrow \mathrm{E}-\mathrm{PP} \cdot \mathrm{AMP}$ is ca. $600 \mathrm{~s}^{-1}$ (15). Thus, under the reaction conditions employed, both ATP binding and catalysis are partially rate limiting.

Figure 5 shows the time courses for $\left[{ }^{14} \mathrm{C}\right] \mathrm{AMP}$ formation catalyzed by $\mathrm{Co}^{2+}$ activated wild-type and R337A PPDKs. The product yield observed at equilibrium was $37 \%$ in the case of the wild-type enzyme and $70 \%$ in the case of the R337A mutant. The data were fit to a single-exponential equation to give a $k_{\mathrm{obs}}=160 \pm 30 \mathrm{~s}^{-1}$ for wild-type PPDK and $k_{\mathrm{obs}}=33 \pm 4 \mathrm{~s}^{-1}$ for R337A PPDK. These data indicate that $\mathrm{Co}^{2+}$ activated R337A PPDK catalyzes the E + ATP $\rightarrow$ E-PP-AMP reaction at a rate 5-fold slower than that of the wild-type enzyme.

Next, the effect of the Arg337 mutation on catalysis of the $\mathrm{E}-\mathrm{PP} \cdot \mathrm{AMP}+\mathrm{P}_{\mathrm{i}} \rightarrow \mathrm{E}-\mathrm{P} \cdot \mathrm{AMP} \cdot \mathrm{PP}_{\mathrm{i}}$ partial reaction was examined. The assay for $\mathrm{E}-\mathrm{P} \cdot \mathrm{AMP} \cdot \mathrm{PP}_{\mathrm{i}}$ employed HPLC separation of unconsumed $\left[{ }^{14} \mathrm{C}\right] \mathrm{ATP}$ reactant and $\left[{ }^{14} \mathrm{C}\right] \mathrm{AMP}$ product from the acid-quenched single turnover reactions of $5 \mu \mathrm{M}\left[{ }^{14} \mathrm{C}\right] \mathrm{ATP}, 20 \mu \mathrm{M}$ PPDK, and $11 \mathrm{mM} \mathrm{P}$. $\mathrm{Mg}^{2+}$ was used as the cofactor so that the equilibrium ratio of $[\mathrm{E}-\mathrm{PP}$. AMP $] /[\mathrm{E} \cdot \mathrm{ATP}]$ would be small (viz. ca. 0.2) (15). Thus, the majority (i.e., ca. $80 \%$ ) of the AMP formed from a single turnover on the enzyme is generated by the E-PP.AMP + $\mathrm{P}_{\mathrm{i}} \rightarrow \mathrm{E}-\mathrm{P} \cdot \mathrm{AMP} \cdot \mathrm{PP}_{\mathrm{i}}$ step, which is driven to completion by

\footnotetext{
${ }^{2}$ The internal equilibrium constant $\mathrm{E}-\mathrm{PP} \cdot \mathrm{AMP} / \mathrm{E} \cdot \mathrm{ATP}$ is 0.2 in the case of the $\mathrm{Mg}^{2+}$-activated enzyme and 0.4 in the case of the $\mathrm{Co}^{2+}$ activated enzyme (15). In addition, the dissociation constant for E. ATP is ca. $100 \mu \mathrm{M}$ in the case of the $\mathrm{Mg}^{2+}$-activated enzyme and ca. $10 \mu \mathrm{M}$ in the case of the $\mathrm{Co}^{2+}$-activated enzyme. Thus, in the equilibrium mixture generated from $5 \mu \mathrm{M}\left[{ }^{14} \mathrm{C}\right] \mathrm{ATP}$ and $40 \mu \mathrm{M}$ PPDK the concentration of E-PP·AMP is significantly higher with $\mathrm{Co}^{2+}$ PPDK than it is with $\mathrm{Mg}^{2+}-\mathrm{PPDK}$. As a result, the time course for $\mathrm{E}-\mathrm{PP} \cdot \mathrm{AMP}$ formation by the $\mathrm{Co}^{2+}$-activated PPDK is more accurately measured since the radioactivity associated with the $\left[{ }^{14} \mathrm{C}\right] \mathrm{AMP}$ product fraction is that much higher (ca. 30\% of the total reactivity for wildtype PPDK) than that found for the control reaction (ca. $1 \%$ of the total radioactivity).
}

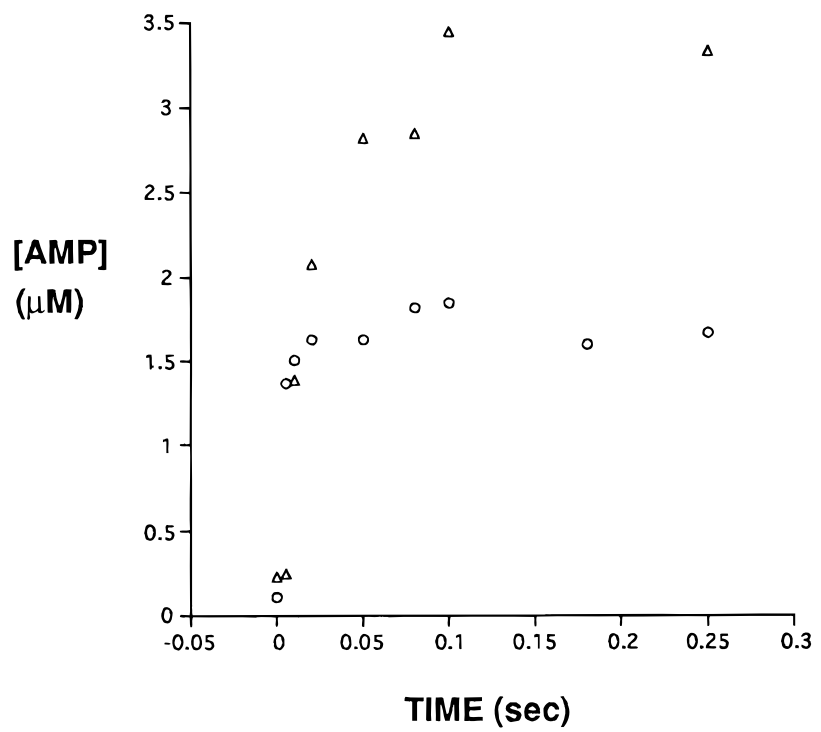

FIGURE 5: Time course for $\left[{ }^{14} \mathrm{C}\right] \mathrm{AMP}$ formation in the single turnover reaction of $40 \mu \mathrm{M}$ enzyme, $5 \mu \mathrm{M}\left[{ }^{14} \mathrm{C}\right] \mathrm{ATP}, 5 \mathrm{mM} \mathrm{CoCl} \mathrm{C}_{2}$, and $10 \mathrm{mM} \mathrm{NH}_{4} \mathrm{Cl}$ in $50 \mathrm{mM} \mathrm{K}+$ Hepes $\left(\mathrm{pH} \mathrm{7.0,} 25^{\circ} \mathrm{C}\right)$ for $(\mathrm{O})$ wild-type PPDK and $(\triangle)$ R337A PPDK.

the high concentration of $\mathrm{P}_{\mathrm{i}}$ present in the reaction. The rate data measured with wild-type PPDK and shown in Figure 6A were fit with a single exponential equation to give $k_{\mathrm{obs}}=5.7 \pm 0.3 \mathrm{~s}^{-1}$ for the combined reaction steps. ${ }^{3} \mathrm{On}$ the other hand, the rate data measured with R337A PPDK (Figure 6B) define a biphasic curve. The fast phase accounted for ca. $0.8 \mu \mathrm{M}\left[{ }^{14} \mathrm{C}\right] \mathrm{AMP}$ product formed while the ensuing slow phase accounted for an additional $3.5 \mu \mathrm{M}$ $\left[{ }^{14} \mathrm{C}\right] \mathrm{AMP}$. The two sets of data points were independently fit to a single exponential equation to yield $k_{\text {lobs }}=140 \pm$ $40 \mathrm{~s}^{-1}$ and $k_{2 \mathrm{obs}}=0.04 \pm 0.002 \mathrm{~s}^{-1}$, where $k_{\text {lobs }}$ reflects the rate of the E + ATP $\rightarrow$ E-PP·AMP partial reaction and $k_{2 \text { obs }}$ reflects the rate of the E-PP·AMP $+\mathrm{P}_{\mathrm{i}} \rightarrow \mathrm{E}-\mathrm{P} \cdot \mathrm{AMP}$. $\mathrm{PP}_{\mathrm{i}}$ partial reaction. ${ }^{4}$

Demonstration of $P P_{i}$ and PEP Product Formation Catalyzed By R337A PPDK. For the kinetic experiments described in the previous section, R337A PPDK catalyzed AMP formation from the reaction of $\left[{ }^{14} \mathrm{C}\right] \mathrm{ATP}+\mathrm{P}_{\mathrm{i}}+$ pyruvate was demonstrated by the isolation of $\left[{ }^{14} \mathrm{C}\right] \mathrm{AMP}$. On the other hand, the formation of $\mathrm{PP}_{\mathrm{i}}$ and PEP in this reaction was assumed. The knowledge that kinases commonly possess intrinsic ATPase activities prompted us to consider alternate hydrolytic pathways involving E-PP or $\mathrm{E}-\mathrm{P}$ which could allow additional catalytic cycles to occur in the absence of $\mathrm{PP}_{\mathrm{i}}$ and/or PEP product formation. Although hydrolysis is not detected in catalysis by wildtype PPDK, the altered active site of the R337A PPDK mutant may facilitate this process. To demonstrate that $\mathrm{P}_{\mathrm{i}}$ is the acceptor of the terminal phosphoryl group from E-PP and pyruvate, the acceptor of the phosphoryl group from

\footnotetext{
${ }^{3}$ On the basis of the rate constants obtained in previous kinetic measurements (15) and on the substrate concentrations used in the present reaction, the ATP and $\mathrm{P}_{\mathrm{i}}$ binding steps are predicted to be rate limiting.

${ }^{4}$ We note that the value of the rate constant obtained for the small burst is only an estimate of the actual rate constant. Data points defining the initial portion of the time course could not be obtained, and thus, the curve was extrapolated from later time points to a value of 0 at time 0 .
} 

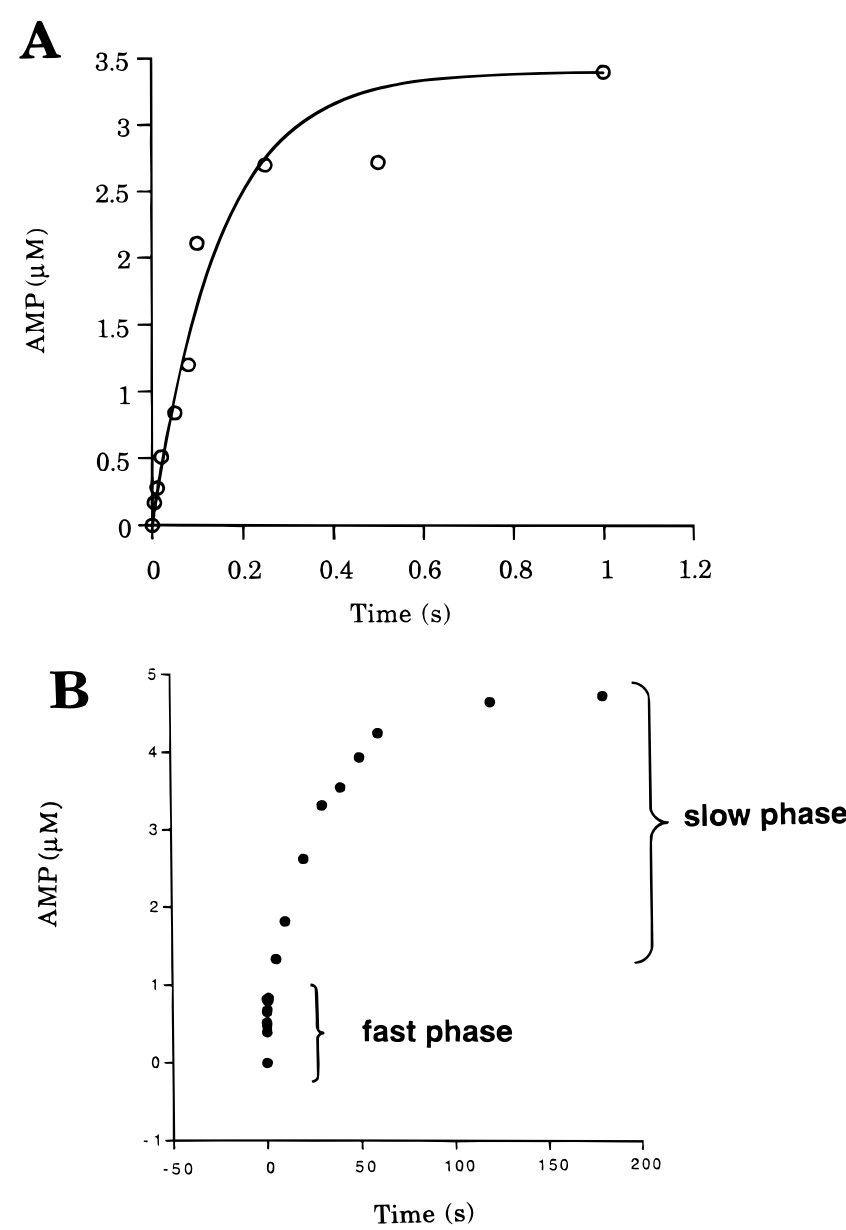

FIgURE 6: Time course for $\left[{ }^{14} \mathrm{C}\right] \mathrm{AMP}$ formation in the single turnover reaction of $20 \mu \mathrm{M}$ enzyme, $5 \mu \mathrm{M}\left[{ }^{14} \mathrm{C}\right] \mathrm{ATP}, 11 \mathrm{mM} \mathrm{P} \mathrm{P}_{\mathrm{i}}, 5$ $\mathrm{mM} \mathrm{MgCl}$, and $10 \mathrm{mM} \mathrm{NH}_{4} \mathrm{Cl}$ in $50 \mathrm{mM} \mathrm{K}^{+}$Hepes (pH 7.0, 25 $\left.{ }^{\circ} \mathrm{C}\right)$. Panels: (A) wild-type PPDK and (B) R337A PPDK.

$\mathrm{E}-\mathrm{P},\left[\gamma_{-}{ }^{32} \mathrm{P}\right] \mathrm{ATP}$, and $\left[{ }^{14} \mathrm{C}\right]$ pyruvate were used as radiolabeled substrates and the time courses for $\left[{ }^{32} \mathrm{P}\right] \mathrm{PP}_{\mathrm{i}}$ and $\left[{ }^{14} \mathrm{C}\right]-$ PEP formation were monitored.

Figure 7 shows the time course for $E-P P$ and $P P_{i}$ formation and ATP consumption in the single turnover of $\left[\gamma^{3}{ }^{32} \mathrm{P}\right] \mathrm{ATP}+\mathrm{P}_{\mathrm{i}}+$ pyruvate catalyzed by wild-type PPDK and R337A PPDK. The levels of E-PP formed in the first reaction step $(\mathrm{E}+\mathrm{ATP} \rightarrow \mathrm{E}-\mathrm{PP} \cdot \mathrm{AMP})$ catalyzed by the two enzymes are comparable $\left(k_{\mathrm{obs}}=300 \mathrm{~s}^{-1}\right.$ for wild-type PPDK and $80 \mathrm{~s}^{-1}$ for R337A PPDK). ${ }^{4} \mathrm{PP}_{\mathrm{i}}$ formation from the second step $\left(\mathrm{E}-\mathrm{PP} \cdot \mathrm{AMP}+\mathrm{P}_{\mathrm{i}} \rightarrow \mathrm{E}-\mathrm{P} \cdot \mathrm{AMP} \cdot \mathrm{PP}_{\mathrm{i}}\right)$ of the reaction was observed for both mutant $\operatorname{PPDK}\left(k_{\mathrm{obs}}=0.04\right.$ $\left.\mathrm{s}^{-1}\right)$ and wild-type PPDK $\left(k_{\mathrm{obs}}=100 \mathrm{~s}^{-1}\right)$.

Figure 8 shows the steady-state time course for PEP formation and pyruvate consumption in the multiple turnover reactions of $\mathrm{ATP}+\mathrm{P}_{\mathrm{i}}+\left[{ }^{14} \mathrm{C}\right]$ pyruvate catalyzed by wildtype PPDK and R337A PPDK. It is evident from these profiles that PEP is formed by R337A PPDK $\left(v_{0} /[\mathrm{E}]=0.004\right.$ $\left.\mathrm{S}^{-1}\right)$ but at a comparatively slower rate than by wild-type $\operatorname{PPDK}\left(v_{0} /[\mathrm{E}]=1.2 \mathrm{~s}^{-1}\right)$.

$X$-ray Crystal Structure of R337A PPDK. The current model has a conventional $R$-factor of 0.180 for the 26796 reflections between 10.0 and $2.5 \AA$ resolution for which $F$ $\geq 2 \sigma(F)\left(R\right.$-factor $=\sum_{h k l}|| F_{\mathrm{o}}|-| F_{\mathrm{c}}|| / \sum_{h k l}\left|F_{\mathrm{o}}\right|$, where $F_{\mathrm{o}}$ and $F_{\mathrm{c}}$ are the observed and calculated structure factors). The stereochemical parameters are well within the range known
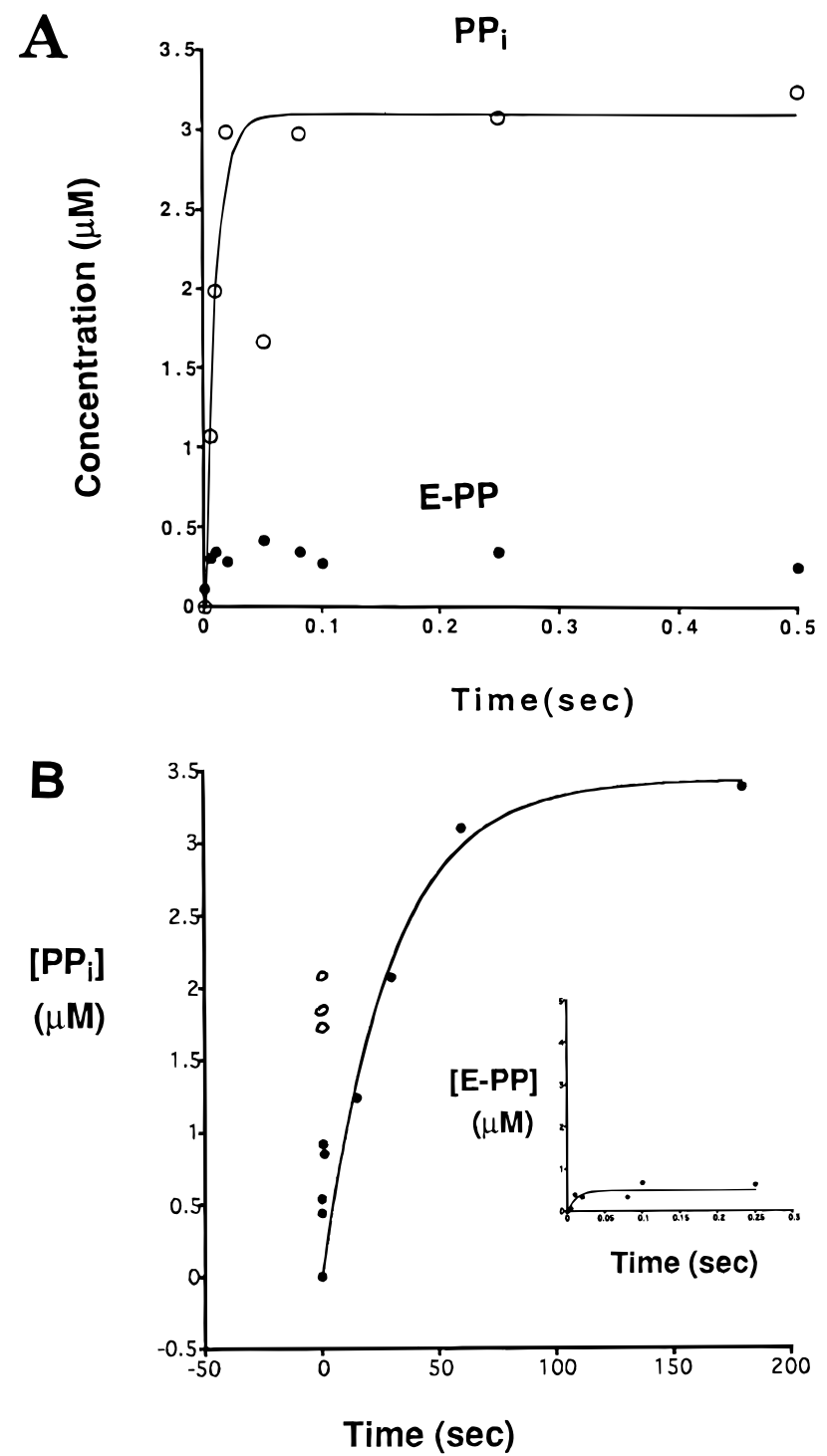

FIGURE 7: Time course for a single turnover reaction of $6 \mu \mathrm{M}$ $\left[\gamma_{-}{ }^{32} \mathrm{P}\right] \mathrm{ATP}, 2 \mathrm{mM} \mathrm{P}, 1 \mathrm{mM}$ pyruvate, $3 \mathrm{mM} \mathrm{MgCl}$, and $10 \mathrm{mM}$ $\mathrm{NH}_{4} \mathrm{Cl}$ in $50 \mathrm{mM} \mathrm{K}{ }^{+}$Hepes $\left(\mathrm{pH} 7.0,25^{\circ} \mathrm{C}\right.$ ) catalyzed by $34 \mu \mathrm{M}$ (A) wild-type PPDK and (B) R337A PPDK. (O). Data points were not included in the exponential fit to the progress curve.

from crystal structures of small peptides. The root-meansquare (rms) deviations from ideal values for bond lengths and bond angles of the standard geometry as compiled by Engh and Huber (24) are $0.018 \AA$ and $2.8^{\circ}$, respectively. The model includes 869 of the 874 amino acid residues (the $\mathrm{N}$-terminal methionine and residues 506-509 are associated with regions of low electron density), 78 water molecules, and 1 sulfate ion. Within the accuracy of the structure determination, the overall structure is the same as that of the wild-type protein (Figure 9) (5). The $\mathrm{C} \alpha$ atomic coordinates of the mutant and wild-type molecules superimpose with a rms deviation of $0.5 \AA$ (Figure 10). The electron density map at the mutation site is consistent with the replacement of an arginine by an alanine residue (Figure 9). A water molecule, WAT2, replaces a sulfate ion that is present in the wild-type PPDK structure, coordinated to Arg337, Lys22, and an oxyanion hole formed by the backbone amide NH groups of Gly101 and Met103 (5). A slight shift of the 99-105 peptide segment accompanies the removal of the sulfate ion. 


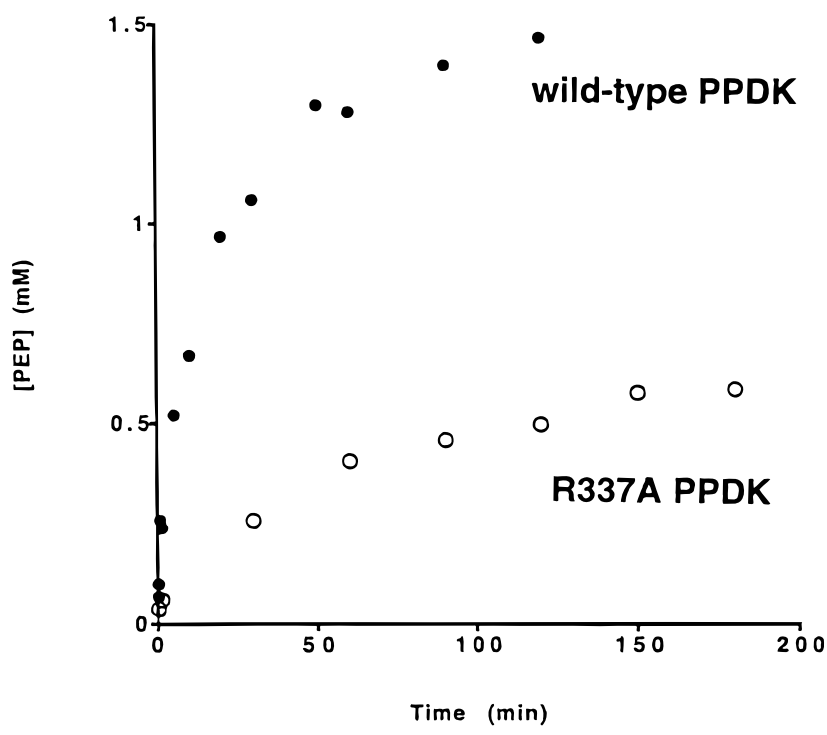

Figure 8: Time course for $\left[{ }^{14} \mathrm{C}\right] \mathrm{PEP}$ formation and $\left[{ }^{14} \mathrm{C}\right]$ pyruvate consumption in the reaction of $2 \mathrm{mM}$ ATP, $5 \mathrm{mM}\left[{ }^{14} \mathrm{C}\right]$ pyruvate, $5 \mathrm{mM} \mathrm{P}$, 20 units of inorganic pyrophosphatase, $5 \mathrm{mM} \mathrm{MgCl}$, and $10 \mathrm{mM} \mathrm{NH}_{4} \mathrm{Cl}$ in $50 \mathrm{mM} \mathrm{K}+$ Hepes $\left(\mathrm{pH} 7.0,25^{\circ} \mathrm{C}\right.$ ) catalyzed by (๑) $1 \mu \mathrm{M}$ wild-type PPDK or (O) $20 \mu \mathrm{M}$ R337A PPDK.

\section{DISCUSSION}

The goal of this work is to determine the location of the $\mathrm{P}_{\mathrm{i}}$ binding site within the three-domain structure of PPDK represented in Figure 1. The ATP binding site is located in the crevice formed between the two $\beta$-sheets of the $\mathrm{N}$ terminal domain (Figure 2). Computer modeling experiments suggested placing the $\mathrm{P}_{\mathrm{i}}$ in this crevice to the righthand (model $\mathrm{A}$ ) or left-hand side (model $\mathrm{B}$ ) of the ATP $\beta$-P. In either arrangement both the ATP $\gamma-\mathrm{P}$ and $\mathrm{P}_{\mathrm{i}}$ interact with the guanidinium side chain of Arg337. Thus, replacement of $\operatorname{Arg} 337$ with an amino acid which cannot interact favorably with the negatively charged substrates should inhibit the E・ATP $\cdot \mathrm{P}_{\mathrm{i}} \rightarrow \mathrm{E}-\mathrm{PP} \cdot \mathrm{AMP} \cdot \mathrm{P}_{\mathrm{i}} \rightarrow \mathrm{E}-\mathrm{P} \cdot \mathrm{AMP} \cdot \mathrm{PP}_{\mathrm{i}}$ reaction sequence, provided that one of the two models proposed in Figure 2 is correct.

Kinetic Study of Arg337 PPDK Mutants. For this study two mutants were prepared: R337K PPDK and R337A PPDK. Steady-state kinetic analysis of the catalysis of the full reaction in the forward and reverse directions showed that both mutants were catalytically impaired (Table 2). The R337A PPDK was found to be less active than the R337K PPDK, indicating that the positively charged Lys side chain at position 337 is more effective in facilitating catalysis than is the methyl substituent of the Ala residue. Surprisingly, close inspection of the composition of the product mixture generated with R337K PPDK revealed that ATP hydrolysis to ADP occurs in competition with the normal reaction pathway. The ATPase activity was not observed with R337A PPDK. The Lys residue at position 337 thus appears to promote the addition of water to the $\beta$-P of the ATP. To avoid complications deriving from this competing reaction, the transient kinetic studies described below were carried out with R337A PPDK. Before executing these kinetic experiments, however, the formation of $\mathrm{PP}_{\mathrm{i}}$ (Figure 7 ) and PEP (Figure 8) as products was first demonstrated (using $\left[\gamma-{ }^{32} \mathrm{P}\right] \mathrm{ATP}$ and $\left[{ }^{14} \mathrm{C}\right]$ pyruvate) to rule out the possibility of other unwanted side reactions (e.g., hydrolysis of E-PP or E-P) during R337A PPDK catalysis.
The transient kinetic studies of R337A PPDK catalysis were carried out for the purpose of determining which of the three partial reactions shown in Scheme 1 is inhibited by the Ala substitution for Arg337. Our prediction was that if the ATP and $\mathrm{P}_{\mathrm{i}}$ ligands are oriented in the active site as shown in model $\mathrm{A}$, the amino acid replacement at position 337 may have only a small inhibitory effect on ATP binding and on catalysis of the E + ATP $\rightarrow$ E-PP-AMP partial reaction (since the interaction with $\operatorname{Arg} 337$ is only one of several electrostatic interactions occurring with the $\gamma$-P) but a stronger inhibitory effect on $\mathrm{P}_{\mathrm{i}}$ binding and on catalysis of the $\mathrm{E}-\mathrm{PP} \cdot \mathrm{P}_{\mathrm{i}} \cdot \mathrm{AMP} \rightarrow \mathrm{E}-\mathrm{P} \cdot \mathrm{PP}_{\mathrm{i}} \cdot \mathrm{AMP}$ partial reaction (since interaction with $\operatorname{Arg} 337$ is the principal interaction of the $\mathrm{P}_{\mathrm{i}}$ with the protein). If, on the other hand, model B is correct, then mutation of Arg337 should strongly inhibit ATP binding and catalysis of the $\mathrm{E}+\mathrm{ATP} \rightarrow \mathrm{E}-\mathrm{PP} \cdot \mathrm{AMP}$ partial reaction (Arg337 contributes the only electrostatic interaction between the protein and the $\gamma$-P) while having a lesser effect on $\mathrm{P}_{\mathrm{i}}$ binding $\left(\mathrm{P}_{\mathrm{i}}\right.$ interacts with the backbone amide NHs of the oxyanion hole and with the side chains of Lys22 and Arg337) and catalysis of the $\mathrm{E}-\mathrm{PP} \cdot \mathrm{P}_{\mathrm{i}} \cdot \mathrm{AMP} \rightarrow \mathrm{E}-\mathrm{P} \cdot \mathrm{PP}_{\mathrm{i}} \cdot \mathrm{AMP}$ partial reaction. Both models predict that the third partial reaction, $\mathrm{E}-\mathrm{P} \cdot$ pyruvate $\rightarrow \mathrm{E} \cdot \mathrm{PEP}$ will not be affected by the amino acid replacement at Arg337 since this reaction occurs on an entirely different domain of the PPDK structure (Figure 1).

The profiles (Figure 3) and rate constants (Table 3) obtained for the single turnover of $\mathrm{E}+\left[{ }^{32} \mathrm{P}\right] \mathrm{PEP} \rightarrow \mathrm{E}-\mathrm{P}$. pyruvate measured for wild-type PPDK and R337A PPDK demonstrate that the substitution of Arg337 with Ala has not significantly altered catalysis of partial reaction 3 (Scheme 1). The profiles (Figure 5) and rate constants (Table 3) measured for the $\mathrm{E}+\left[{ }^{14} \mathrm{C}\right] \mathrm{ATP} \rightarrow \mathrm{E}-\mathrm{PP} \cdot\left[{ }^{14} \mathrm{C}\right] \mathrm{AMP}$ partial reaction indicate that catalysis occurs ca. 5-fold slower in the mutant enzyme than in the wild-type PPDK. The profiles (Figure 6) and rate constants (Table 3) observed for the sequential reactions $\mathrm{E}+\left[{ }^{14} \mathrm{C}\right] \mathrm{ATP}+\mathrm{P}_{\mathrm{i}} \rightarrow \mathrm{E}-\mathrm{PP} \cdot\left[{ }^{14} \mathrm{C}\right] \mathrm{AMP} \cdot$ $\mathrm{P}_{\mathrm{i}} \rightarrow \mathrm{E}-\mathrm{P} \cdot\left[{ }^{14} \mathrm{C}\right] \mathrm{AMP} \cdot \mathrm{PP}_{\mathrm{i}}$ indicate that the E-PP. $\left[{ }^{14} \mathrm{C}\right] \mathrm{AMP} \cdot$ $\mathrm{P}_{\mathrm{i}} \rightarrow \mathrm{E}-\mathrm{P} \cdot\left[{ }^{14} \mathrm{C}\right] \mathrm{AMP} \cdot \mathrm{PP}_{\mathrm{i}}$ step is catalyzed by R337A PPDK at a rate that is ca. 140-fold slower than that observed for wild-type PPDK. These results suggest that the $\mathrm{P}_{\mathrm{i}}$ binding site is located to the right of the ATP $\beta$-P within the PPDK $\mathrm{N}$-terminal domain, as is illustrated in model A of Figure 2.

There are two other pieces of experimental data which support the ligand arrangement shown in model A over that shown in model B. First, $\mathrm{P}_{\mathrm{i}}$ binding is weak $\left(K_{\mathrm{d}}>1 \mathrm{mM}\right)$ (15), and second, it follows ATP binding (19). Both properties are more compatible with $\gamma$-P binding to the putative oxyanion hole and $\mathrm{P}_{\mathrm{i}}$ binding to the left, thereby desolvating the $\gamma$-P.

Structural Analysis of R337A PPDK. With the exception of the mutation site, the crystal structure of the R337A PPDK (Figures 9 and 10) closely resembles the structure of the wildtype protein. Thus, the altered kinetic properties observed for this mutant are attributed solely to the elimination of the interaction between substrate and the guanidinium group of the Arg337 side chain. We note that the sulfate ion bound to the Arg337 guanidinium ion in the wild-type PPDK crystal is absent (i.e., replaced by a water molecule; Figure 9) from the crystal structure of R337A PPDK. This sulfate ion occupies the same position occupied by the $\gamma$-P of ATP in model A (Figure 2). The reduction in binding affinity for 

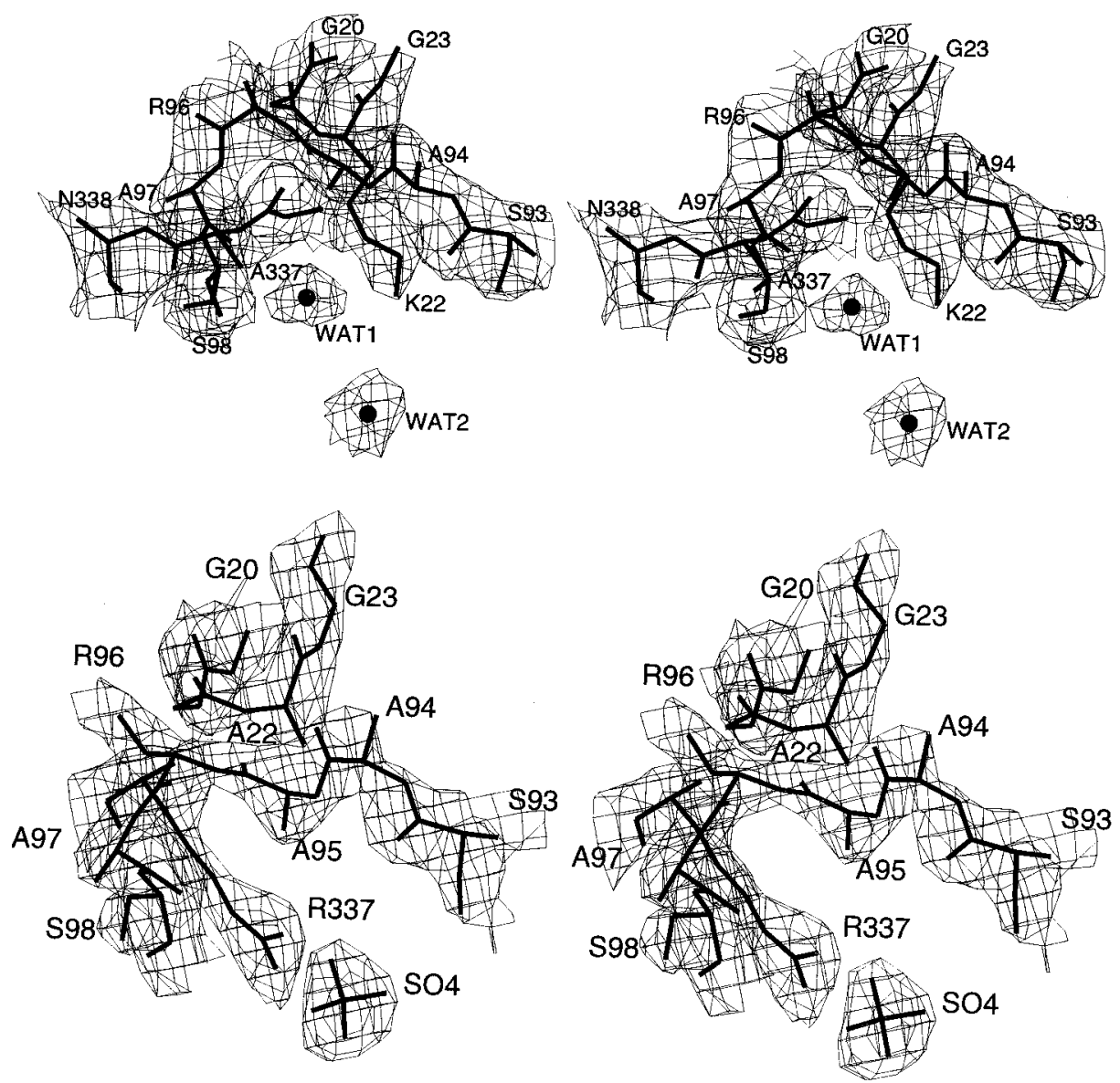

FIGURE 9: (Top) Electron density map showing the mutation site of the R337A PPDK mutant. The map is contoured at the 1.2 $\sigma$ level with map coefficients $\left(2 F_{\mathrm{o}}-F_{\mathrm{c}}\right)$ and calculated phases. Two water molecules, WAT1 and WAT2, are coordinated to Lys 22 . WAT2 is located in an equivalent position to a sulfate ion in the wild-type structure (Bottom).
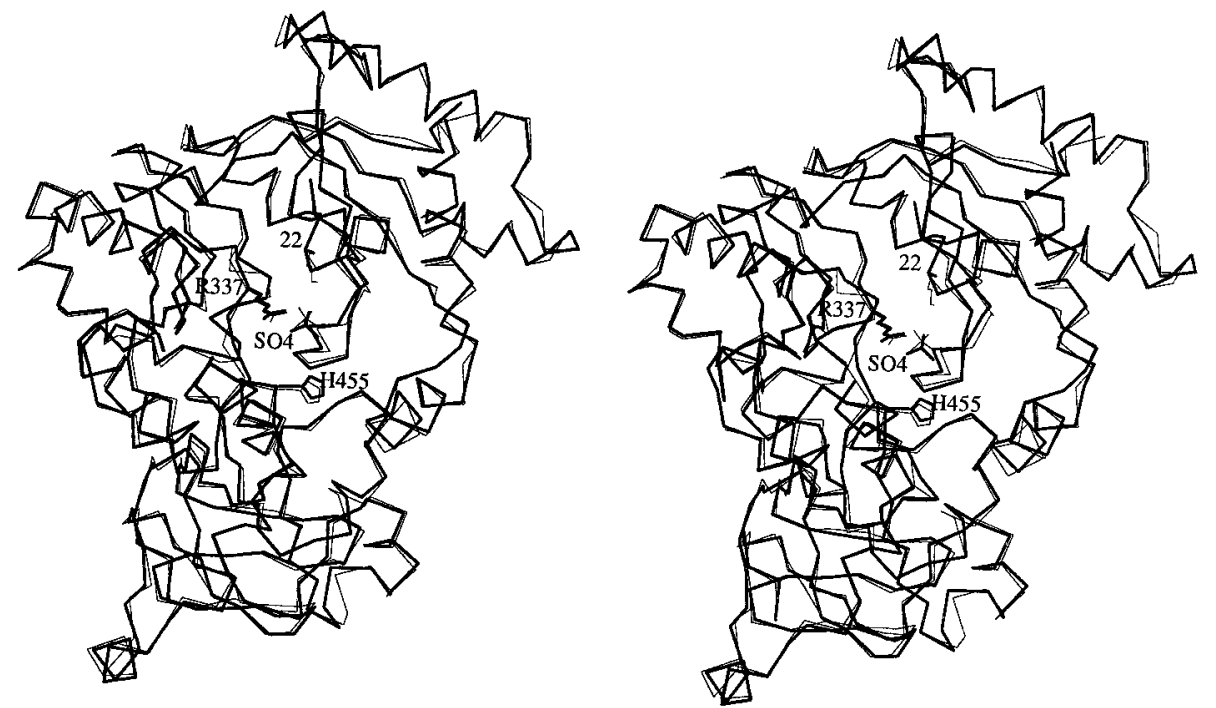

FIGURE 10: Superposition of R337A PPDK (thick lines) and wild-type PPDK (thin lines) N-terminal (ATP/ $\mathrm{P}_{\mathrm{i}}$ binding) and central (catalytic His455) domains. The PEP/pyruvate binding domain (residues 534-874) and residues 109-200 are omitted here for the sake of clarity. Side chains of residues 337, Lys22, and His455 are shown and labeled. As a result of the mutation, a water molecule replaces the Arg337 coordinated sulfate ion present in wild-type PPDK.

the sulfate ion is suggestive that a reduction in binding of the $\gamma$-P of the ATP may also occur in R337A PPDK. Assuming that this interaction contributes to productive binding and/or transition state stabilization, it may explain why a (5-fold) reduction in the rate of nucleophilic displacement of the $\gamma$-P $\beta$-P unit from ATP is observed for the mutant enzyme (Table 3 ).
Proposed Mechanism of Catalysis. The reaction sequence shown in Figure 11 summarizes the interactions that may occur between $\mathrm{Mg}^{2+}$ cofactor, substrate ligands, and enzyme active site residues during catalytic turnover of ATP and $\mathrm{P}_{\mathrm{i}}$ (Figure 2). The precise positioning of the substrate/ intermediate/product/ $\mathrm{Mg}^{2+}$ ligands shown is purely hypothetical as are the interactions envisioned to occur between 
Table 3: Rate Constants for Single Turnover Reactions Catalyzed by R337A PPDK and Wild-Type PPDK in $50 \mathrm{MM} \mathrm{K}^{+}$Hepes (pH 7.0) at $25^{\circ} \mathrm{C}$

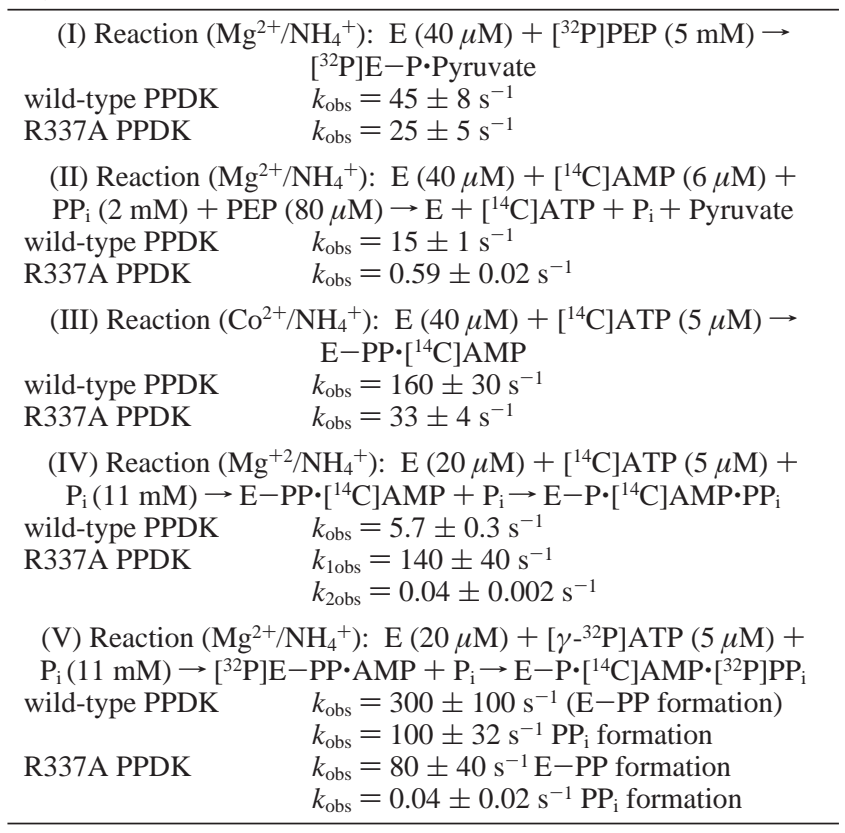

ligands and the enzyme active site residues. Figure 11 is simply a working model for PPDK catalysis that will be tested in future studies. The location selected for the ATP binding site is based on the results from previous affinity labeling studies (9) and on the superposition of the ADP liganded D-Ala-D-Ala ligase (6) with apoPPDK $(5,9)$. From previous kinetic studies (15) we know that the $\mathrm{P}_{\mathrm{i}}$ binding step can (and at moderate $\mathrm{P}_{\mathrm{i}}$ concentrations surely does) occur after ATP has bound and reacted with the enzyme His455. Thus, in our model we show the first step of the reaction occurring from the enzyme $\cdot \mathrm{Mg} \cdot \mathrm{ATP}$ Michaelis complex. While the $\mathrm{Mg}^{2+}$ ligands have not yet been identified, the coordination of $\mathrm{Mg}^{2+}$ to Glu323 shown in Figure 11 is consistent with the results from site-directed mutagenesis experiments which have demonstrated that Glu323 is essential for PPDK catalysis (25). This arrangement places $\mathrm{Mg}^{2+}$ within interaction distance of the ATP $\alpha-\mathrm{P}$ and $\beta$-P. Studies aimed at identifying the actual $\mathrm{Mg}^{2+}$ enzyme ligands and ATP coordination sites are in progress.

In the model, the $\gamma$-P of the ATP is proposed to engage in electrostatic interactions with the backbone amide NHs of Gly101 and Met103, with the guanidinium group of Arg337, and with the ammonium group of Lys22. Lys22 is essential for ATP turnover (25), and Arg337 facilitates ATP turnover (this study). The backbone region containing Gly101 and Met103 appears to form a classical oxyanion hole however, its actual function has yet to be experimentally tested. His455 of the central domain is oriented for in-line

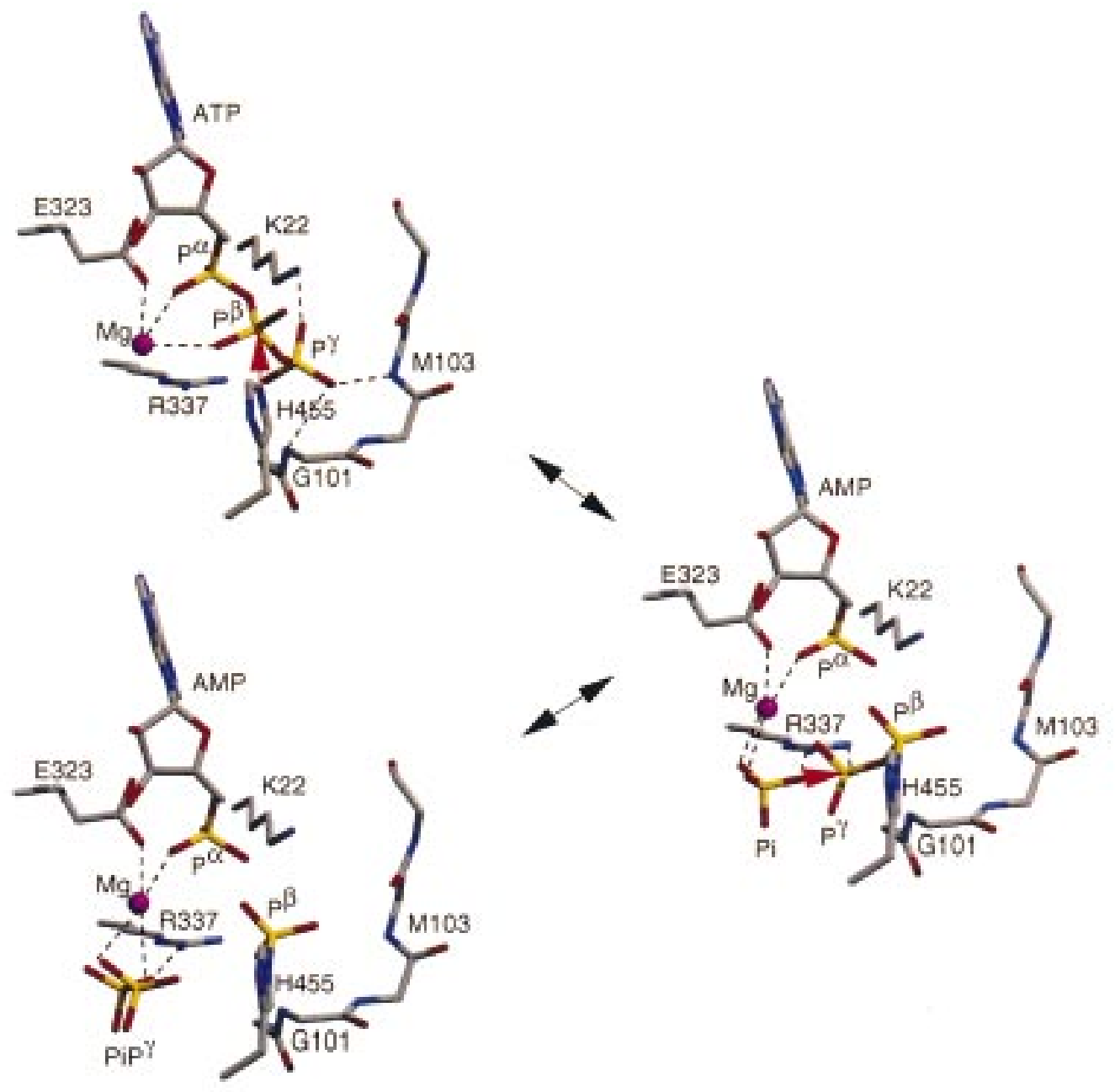

FIGURE 11: Hypothetical three-dimensional model for the progress of the two phosphoryl group transfer reactions that occur in the nucleotide binding site of PPDK. The color scheme is the same as that used in Figure 2. See text for details. 
attack of the ATP $\beta$-P. As the E-PP•Mg $\cdot \mathrm{AMP}$ complex is formed, the $\gamma-\mathrm{P}$ is envisioned to rotate away from Lys 22 and the oxyanion hole, toward the $\mathrm{P}_{\mathrm{i}}$ site. On the basis of the studies presented in this paper, $\mathrm{P}_{\mathrm{i}}$ is believed to bind to Arg337. Although not yet tested, $\mathrm{Mg}^{2+}$ may also bind the $\mathrm{P}_{\mathrm{i}}$ ligand to generate the $\mathrm{E}-\mathrm{PP} \cdot \mathrm{Mg} \cdot \mathrm{AMP} \cdot \mathrm{P}_{\mathrm{i}}$ complex represented in Figure 11. In this complex, the E-PP may be activated for in-line attack by the $\mathrm{P}_{\mathrm{i}}$ through interaction of the $\gamma$-P with Arg337 and the $\beta$-P with the backbone amide NH of Gly101. Future crystallographic and mutagenesis studies will serve as a test for this proposed model of PPDK catalysis.

\section{SUPPORTING INFORMATION AVAILABLE}

Figures 1-3 showing the time courses for the full reaction of ATP, $\mathrm{P}_{\mathrm{i}}$, and pyruvate with wild-type, R337A, and R337K PPDK (5 pages). Ordering information is given on any current masthead page.

\section{REFERENCES}

1. Wood, H. G., Obrien, W. E., and Michaels, G. (1977) Adv. Enzymol. 45, 85-155.

2. Saavedralira, E., and Perezmontfort, R. (1996) Arch. Med. Res. 27, 257-264; Saavedralira, E., Ramirezsilva, L., and Perezmontfort, R. (1998) Biochim. Biophys. Acta-Protein Struct. Enzymol. 1382, 47-54; Park, J. H., Schofield. P. J., and Edwards, M. R. (1997) Exp. Parasitol. 87, 153-156.

3. Matsukoka, M., Ozeki, Y., Yamamoto, N., Hirano, H., KanoMurakami, Y., and Tanaka, Y. (1988) J. Biol. Chem. 263, 11080; Nevalainen, L., Hrdy, I., and Muller, M. (1996) Mol. Biochem. Parasitology 77, 217-223; Bruderer, T., Wehrl, C., and Kohler, P. (1996) Mol. Biochem. Parasitol. 77, 225-233; Bruchhaus, I., and Tanniche, E. (1993) Mol. Biochem. Parasitol. 62, 153-156.

4. Pacolyko, D. J., Carroll, L. J., Martin, B. M., Babbitt, P. C., and Dunaway-Mariano, D. (1990) Biochemistry 29, 1075710765.

5. Herzberg, O., Chen, C. C. H., Kapadia, G., McGuire, M., Carroll, L. J., Noh, S. J, and Dunaway-Mariano (1996) Proc. Natl. Acad. Sci. 93, U.S.A. 2652-2657.

6. Fan, C., Moews, P. C., Walsh, C. T., and Knox, J. R. (1994) Science 266, 439-443; Fan, C., Moews, P. C., Shi, Y., Walsh, C. T., and Knox, J. R. (1995) Proc. Natl. Acad. Sci. U.S.A. 92, 1172-1176.

7. Wolodko, W. T., Fraser, M. E., James, M. N. G., and Bridger, W. A. (1994) J. Biol. Chem. 269, 10883-10890.
8. Yamaguchi, H., Koto, H., Hata, Y., Nishioka, T., Kirmara, A., Oda, J., and Katsube, Y. (1993) J. Mol. Biol. 229, 10831100.

9. Carroll, L. J., Xu, Y., Thrall, S. H., Martin, B. M., and Dunaway-Mariano, D. (1994) Biochemistry 33, 1134-1142; McGuire, M., Carroll, L. J., Yankie, L., Thrall, S. H., Dunaway-Mariano, D., Herzberg, O., Jayaram, B., and Haley, B. H. (1996) Biochemistry 35, 8544-8552.

10. Goss, N. H., Evans, C. T., and Wood, H. G. (1980) Biochemistry 19, 5805-5809.

11. Larsen, T. M., Laughlin, L. T., Holden, H. M., and Rayment, I. (1994) Biochemistry 33, 6301-6309.

12. Xu, Y., Yankie, L., Shen, L., Jung, Y. S., Mariano, P. S., Dunaway-Mariano, D., and Martin, B. M. (1995) Biochemistry 34, 2181-2187; Yankie, L., Xu, Y., and Dunaway-Mariano, D. (1995) Biochemistry 34, 2188-2194.

13. Carroll, L. J., Mehl, A. F., and Dunaway-Mariano, D. (1989) J. Am. Chem. Soc. 111, 5965-5967.

14. Xu, Y., McGuire, M., Dunaway-Mariano, D., and Martin, B. M. (1995) Biochemistry 34, 2195-2202.

15. Mehl, A., Xu, Y., and Dunaway-Mariano, D. (1994) Biochemistry 33, 1093-1102.

16. Sambrook, J., Fritsch, E. F., and Maniatis, T. (1989) Molecular Cloning, 2nd ed., Cold Spring Habor Press, New York.

17. Erlich, H. A., Ed. (1992) PCR Technology Principles and Applications for DNA Amplification, W. H. Freeman and Co., New York.

18. Sanger, F., Miklen, S., and Coulson, A. R. (1977) Proc. Natl. Acad. Sci. U.S.A. 74, 5463.

19. Wang, H. C., Ciskanik, L., Dunaway-Mariano, D., Von der Saal, W., and Villafranca, J. J. (1988) Biochemistry 27, 625633.

20. Howard, A. J., Gilliland, G. L., Finzel, B. C., Poulos, T., Ohlendorf, D. O., and Salemme, F. R. (1987) J. Appl. Crystallogr. 20, 383-387.

21. Brunger, A. T. (1992) X-PLOR Version 3.1: A System for $X$-ray Crystallography and NMR, Yale University Press, New Haven, CT, and London.

22. Roussel, A., and Cambillu, C. (1989) TURBO-FRODO, in Silicon Graphics Geometry Partners Directory, pp 77-78, Silicon Graphics, Mountain View, CA.

23. Tronrud, D. E. (1992) Acta Crystallogr. A48, 912-916.

24. Engh, R. A., and Huber, R. (1991) Acta Crystallogr. A47, 392-400.

25. McGuire, M. V. (1996) Ph.D. Thesis, University of Maryland, College Park, MD. Coordinates have been deposited into the Brookhaven Protein Data Bank (entry code xxx).

BI980920I 